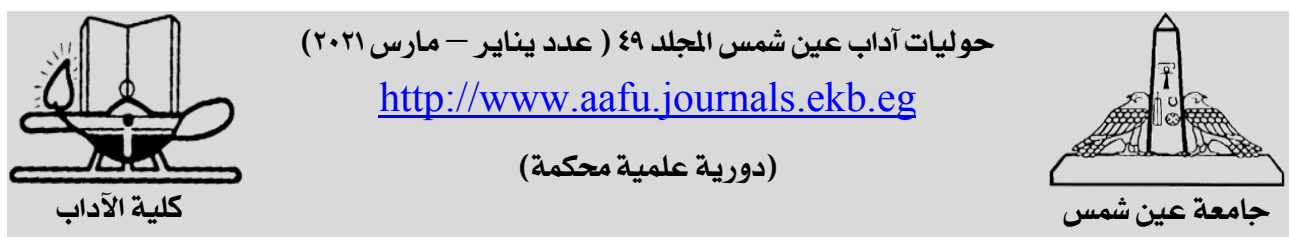

\title{
عقوبة النفي في الفقه الإسلامي وتطبيقاتها المعاصرة
}

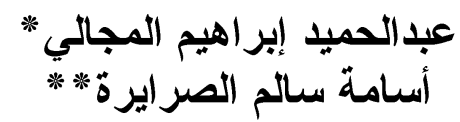

* قسم الفقه و أصوله / جامعة مؤتة / الاردن

d-majali7@yahoo.com

osasms1970@yahoo.com

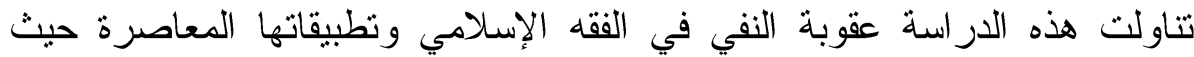
وردت عقوبة النفي في حد الحرابة كعقوبة حدية لإخافة السبيل و إرعاب الإبة المجتمع و أقو ال

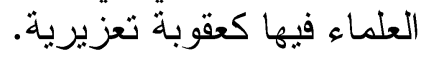
وقد خلصت هذه الدر اسة إلى أن عقوبة النفي هي عقوبة حدية ثابتة بنص القرآن

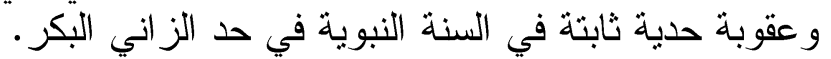

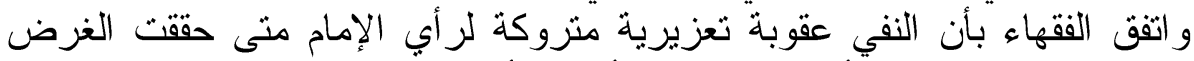

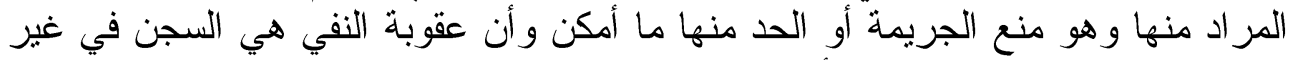

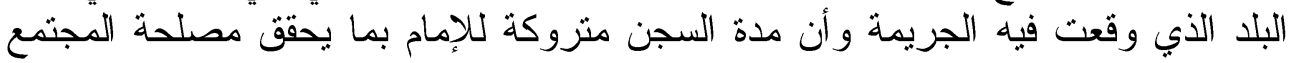

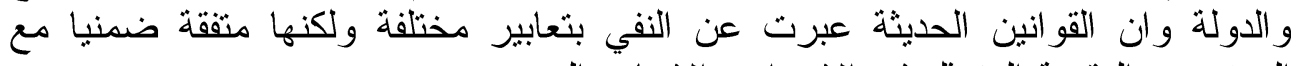

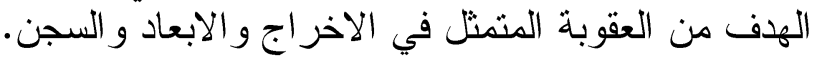


الحمد لله رب العالمين و الصلاة و السلام على المبعوث رحمة للعالمين نبينا محمد

$$
\text { و على آله وصحبه ومن دعا بدعوته و اهتدى بهديه إلى يوم الدئل الدين وبعد. }
$$

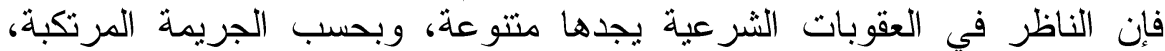

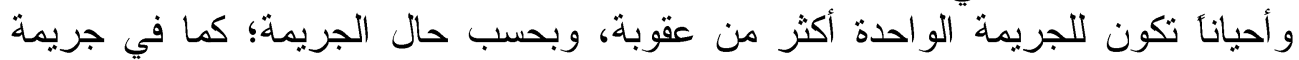
الحر ابة التي تتو عت فيها العقوبات بحسب غلظة وقساوة الجريمة المرتكبة.

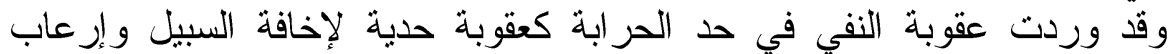

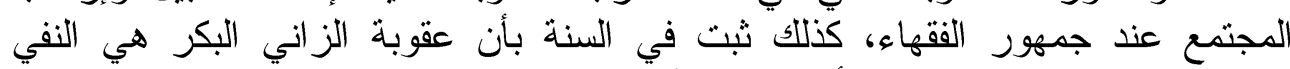

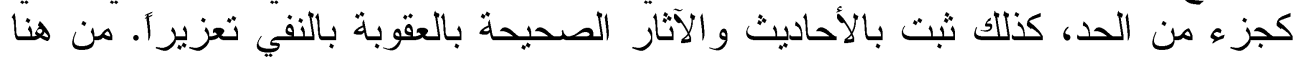
جاءت فكرة هذا البحث في التعريف بعقوبة النفي كعقوبة حدية، و أقو ال العلماء فيها،

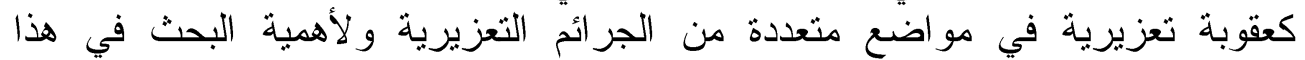
الموضوع؛ لبيان المعالجة الشرعية لتلك الجرائم لبيان تفوق الفقه الإسلامي في مكافحة

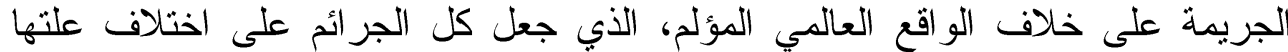

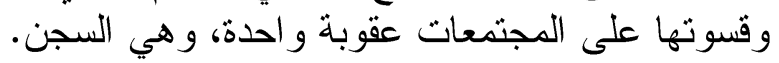

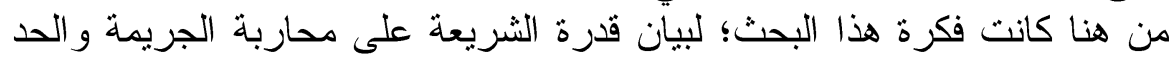

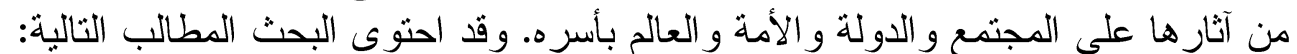

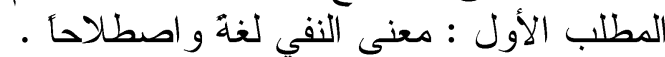
المطلب الثاني : أقو ال العلماء في كيفية تتفيذ عقوبة النفية النفي .

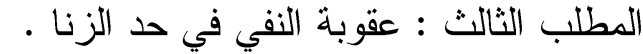

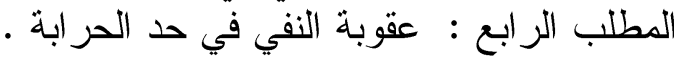

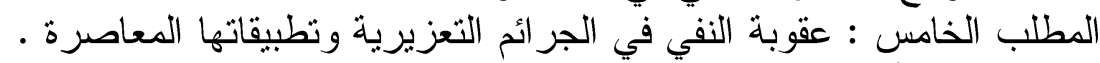

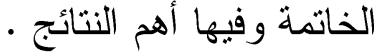

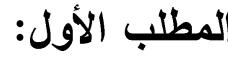

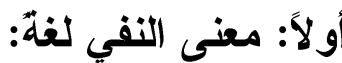

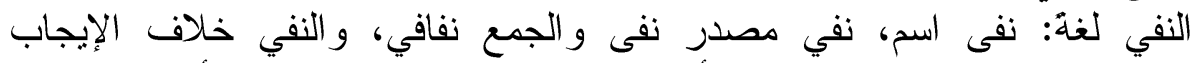

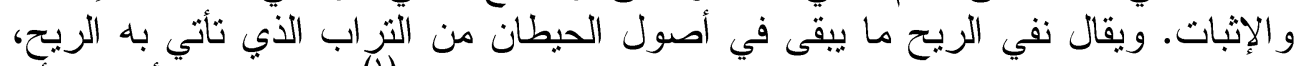

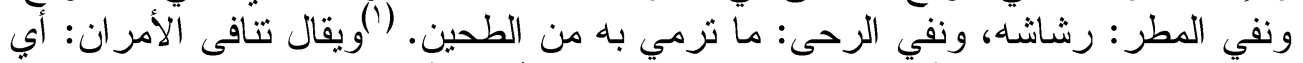

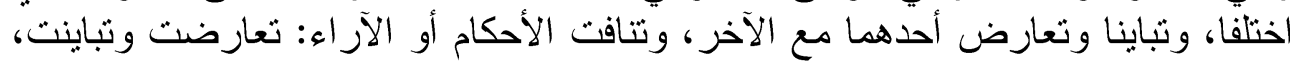

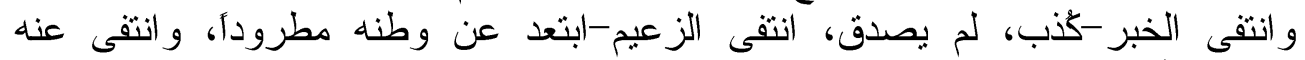

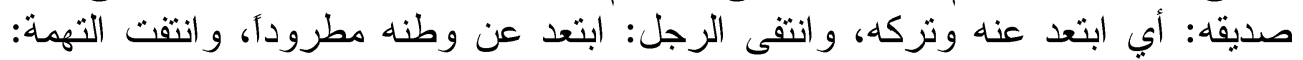
و المعنى المراد في هذه الإراسة: هو معنى الطرد و الإبعاد و الإخر اج، وكلها

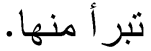

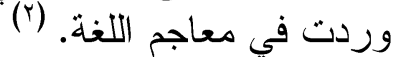

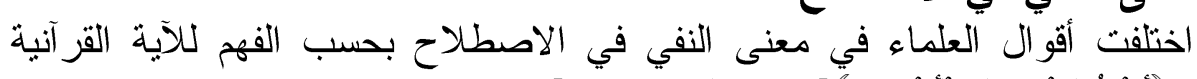
ثانياً: معنى النفي في الاصطلاح:

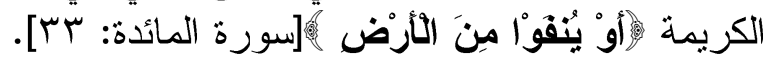




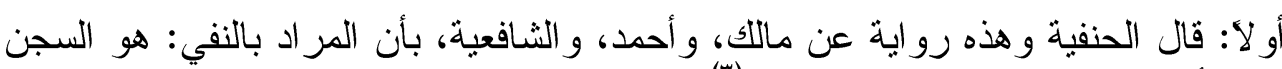

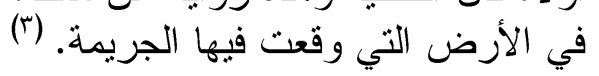

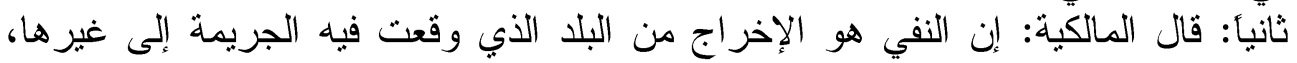

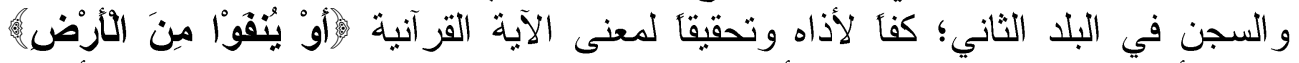

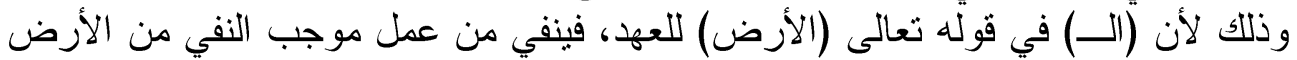

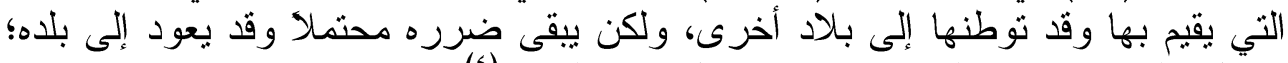

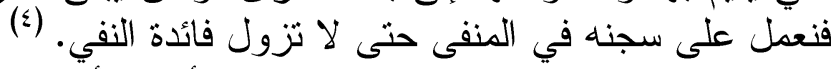

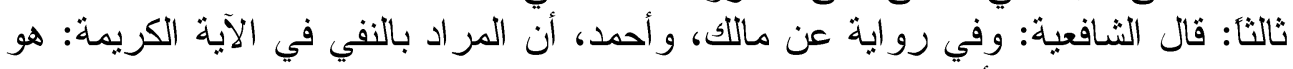

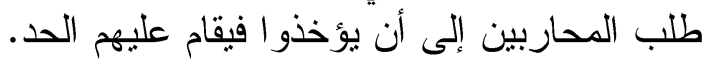
وبهذا قال بعض السلف: يطلب حتى يقدر علئ ئليه فيقام عليه الحد، أو يهرب من دار

(الإسـلام. (0)

و الحقيقة أن هذا المعنى لا يعتبر عقوبة للنفي الذي يعد وبحسب آية الحرابة

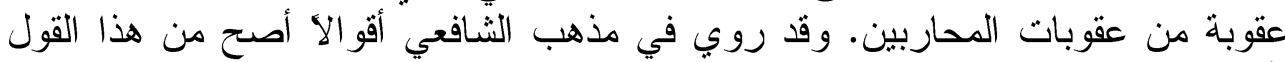

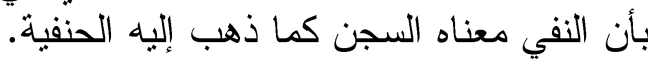

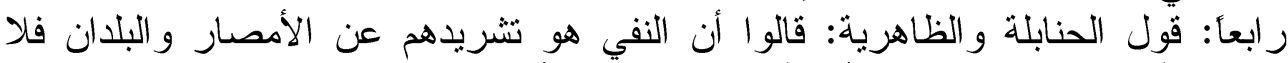

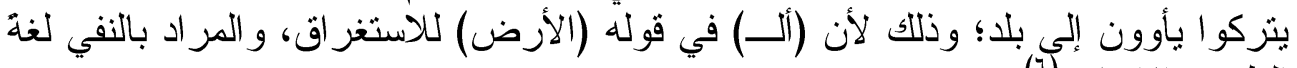

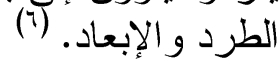

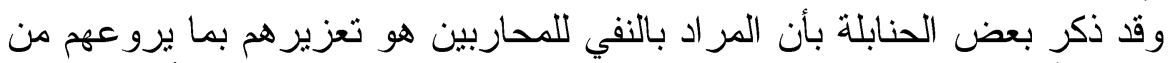

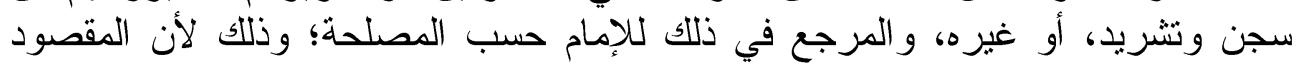

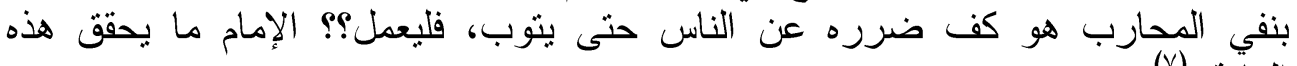

يقول الدكتور عبد العزيز عامر: ((والرأي عندي أنه لما كان المقصود بالنفي

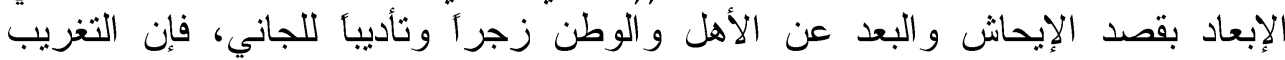

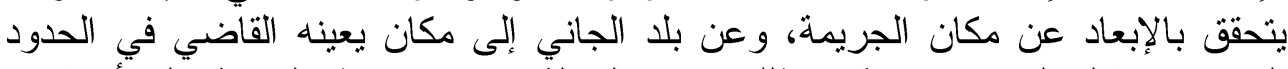

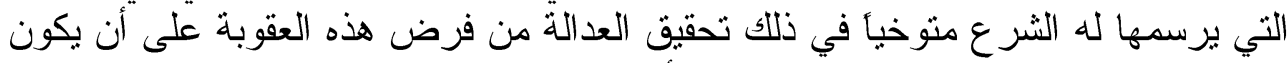
المكان المغرب إلبه في دار الإسلام على أن بيخل في الحسبان تقدم وسائل المو اصلئل

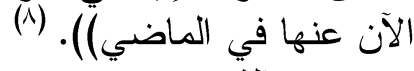

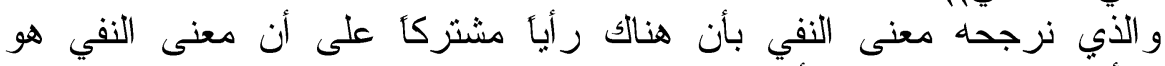

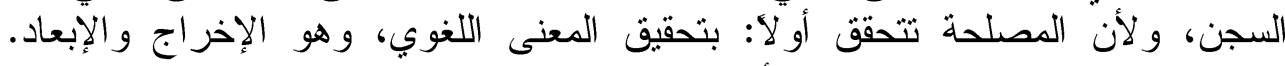

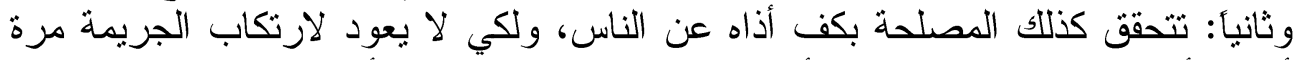

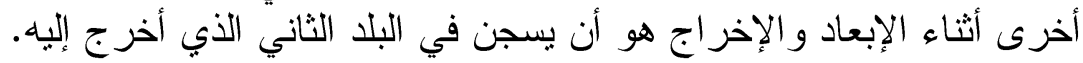

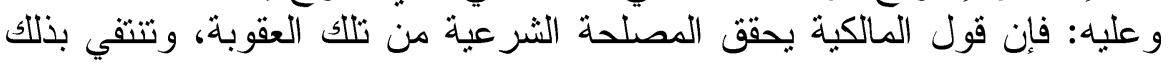

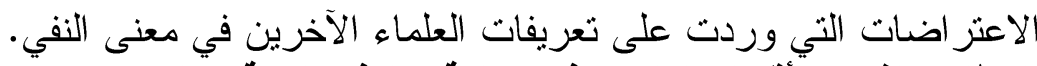
المطلب الثاني: أقوال العلماء في كيفية تنفيذ عقوبة التهية النفي:

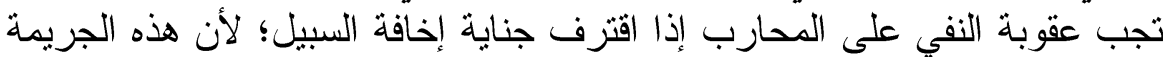

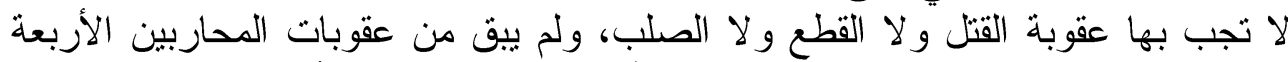

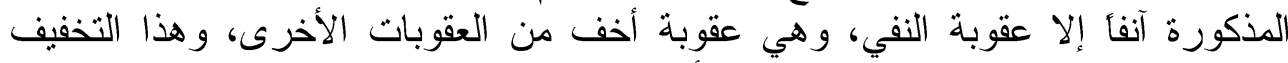

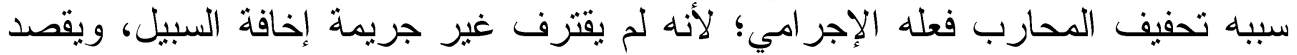


بالنفي الحب، قال السرخسي: "المر اد بالنفي الحبس عندنا في حَّق من خوف الناس ولم

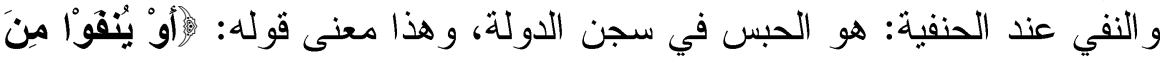

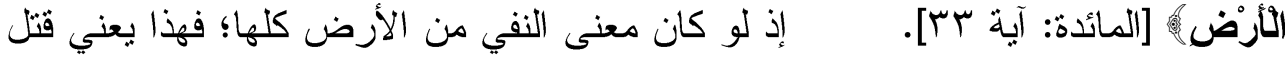

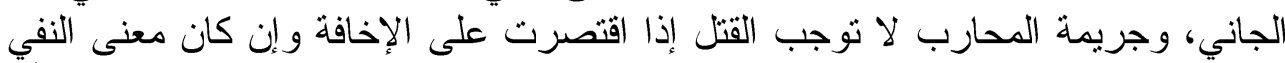

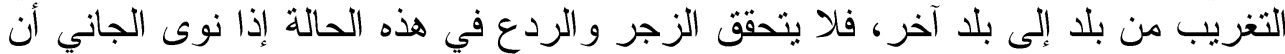

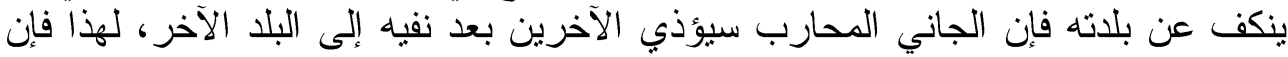

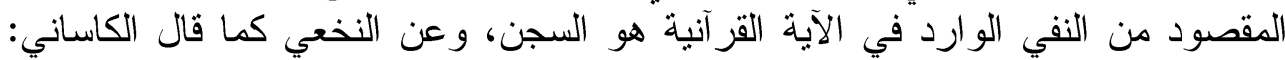

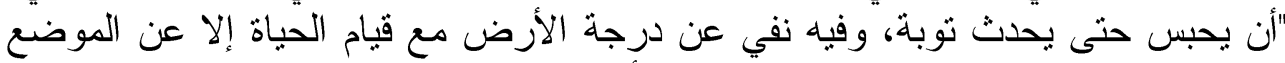

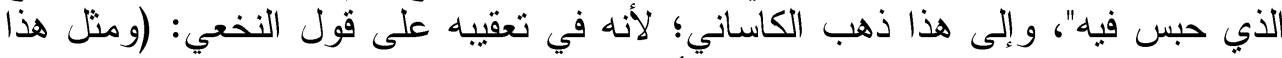

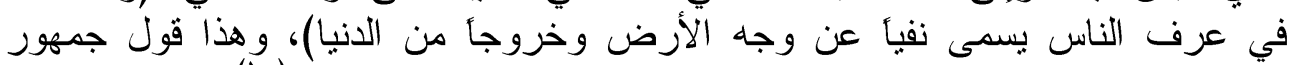

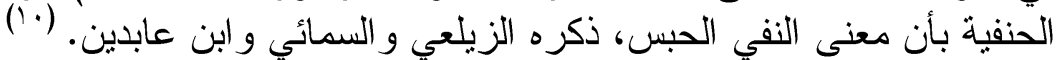
و الراجح عند الجصاص وابن عابدين حبس الجاني في بلده لانتقاء الموجب في الني نقله إلى بلد آخر.

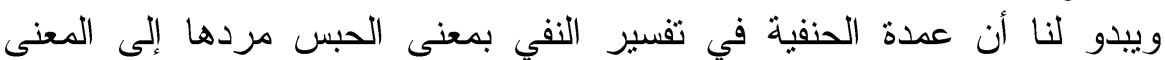

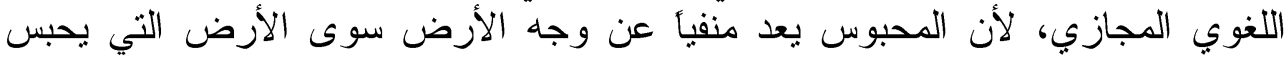

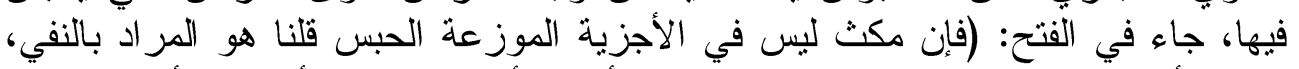

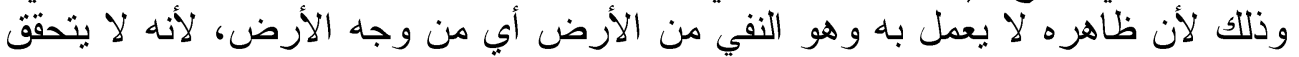

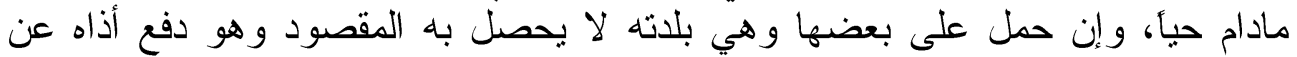

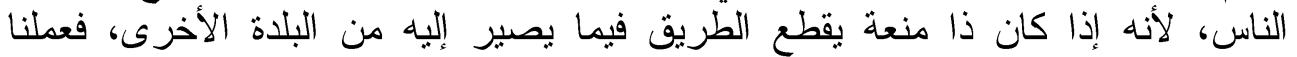
بمجازه و هو الحبس فإنه قد بطلق عليه أنه خارج من الدنيا قال الثاعر في تأكيد هذا لأليا

علسنا من الأحياء فيها ولاء الموتي)

خزجنا من الدنيا ونحن من أهلها

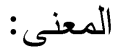

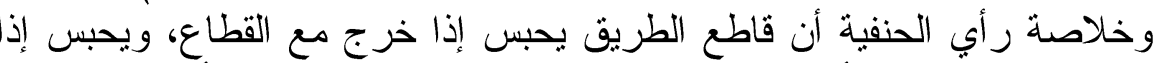

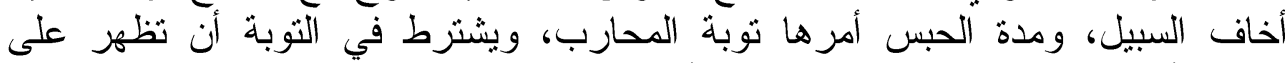

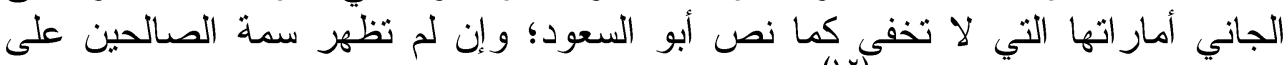

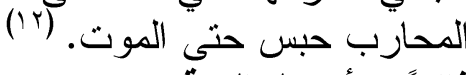

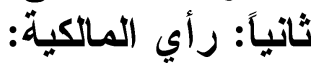

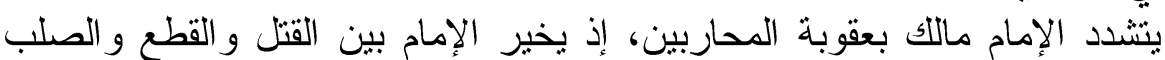

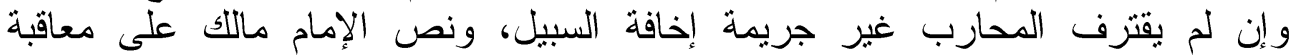

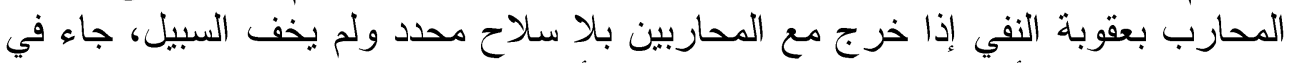

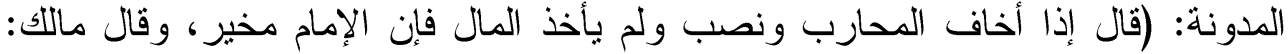

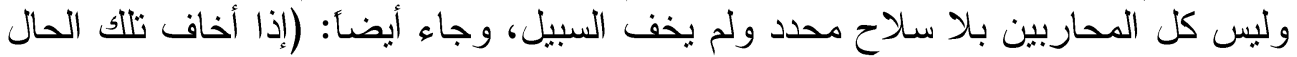

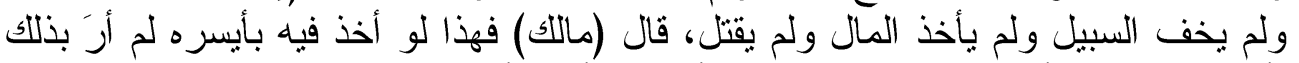

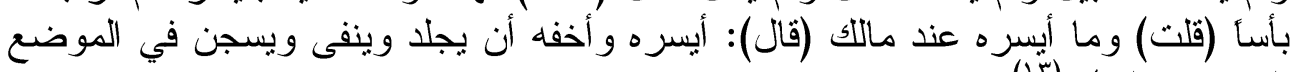


ومدة سجن المنفي معلقة على توبة الجاني وصلاحهه، وذكر ابن رشد أن النفي

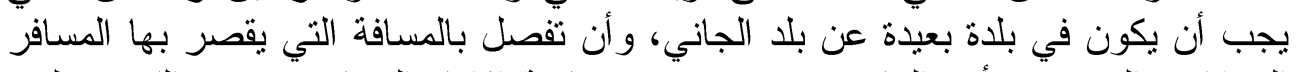

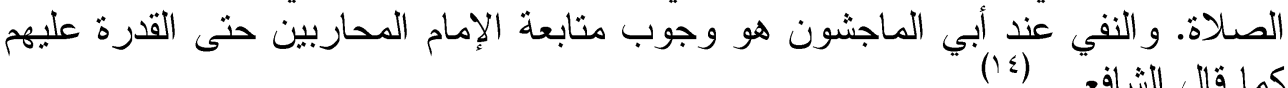

و لا ضرب مع النفي عند بعض فقهاء المالكية؛ لأن القرآن الكريم لم يجعل عقوبة فية

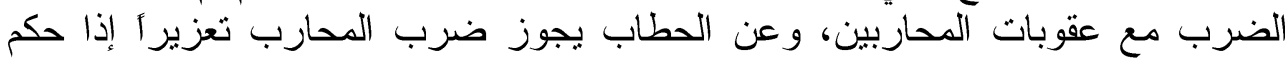
عليه بالنفي، والنفي عقوبة غير قابلة للإسقاط تحدد من قبل فيل الإمام حسب فئ مدى فساد

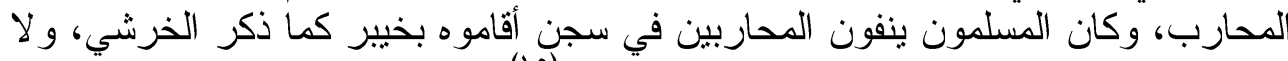

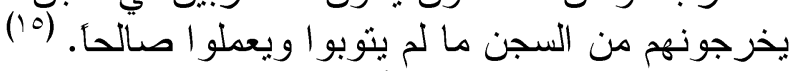

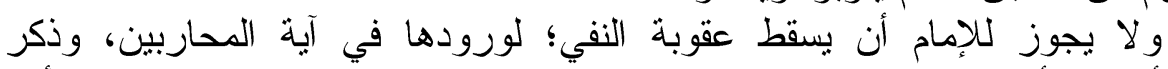

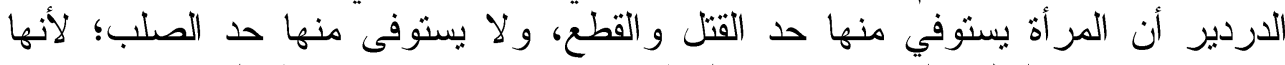

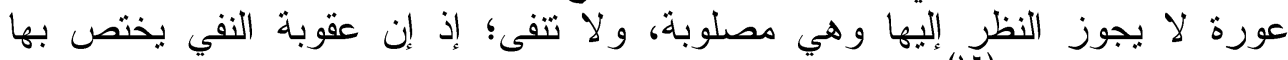

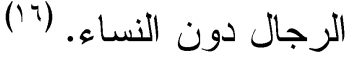
و النفي عند ابن العربي: هو السجن؛ إذ لاء يجوز مطاردة المحارب إلى دار الحرب خشية الارتداد عن الدين. (IV)

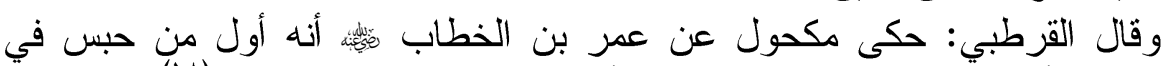

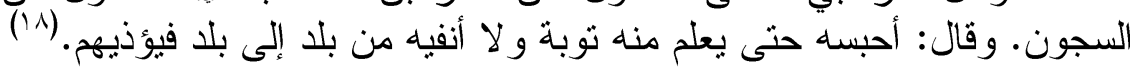

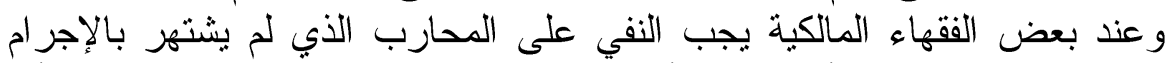

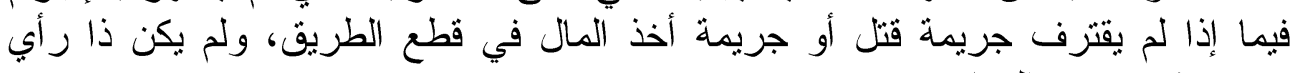
وتدبيز في توجيه الجناة.

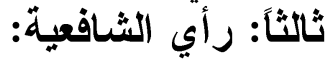
تجب عقوبة النفي عند الثافعية على المحاربين إذا علم الإمام بإخافتهم سبل

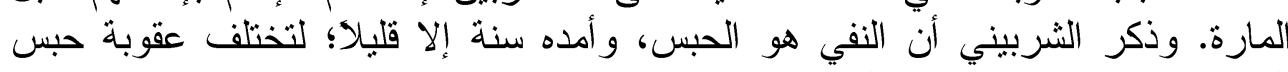

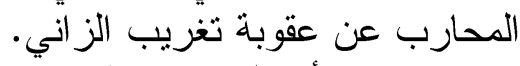
وبما أن النفي عقوبة تعزيرية عند الثافعية؛ فيجوز للإمام أن يضيف مع الحبـ الحبس

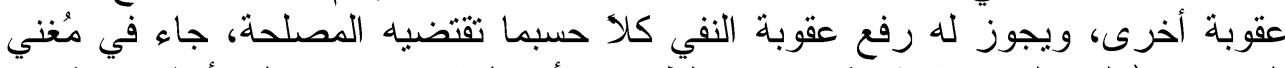

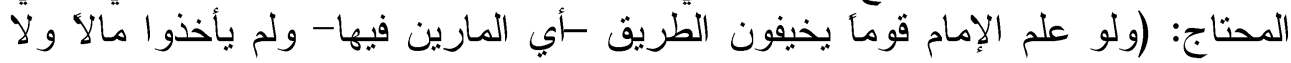

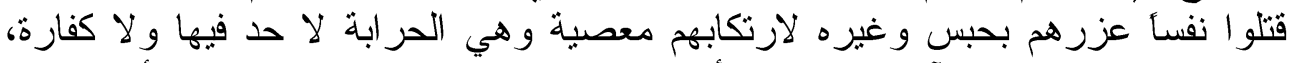

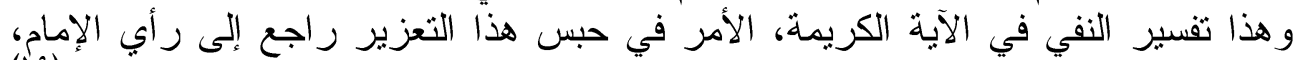

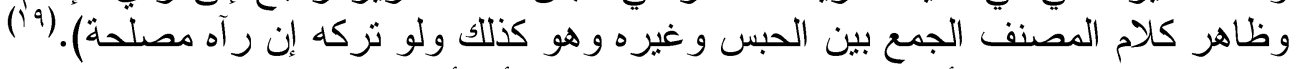

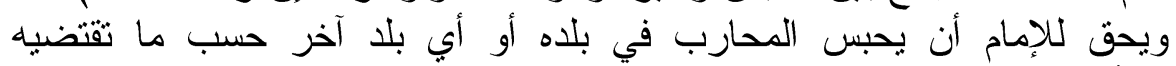

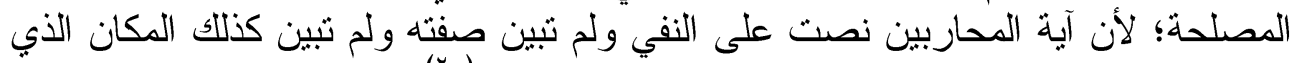

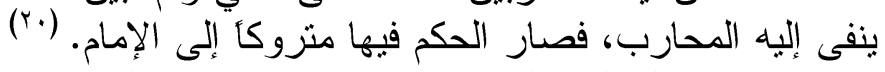

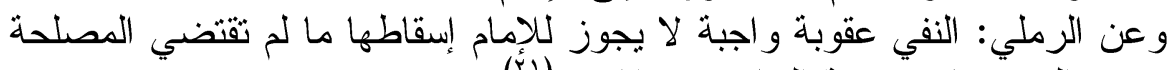

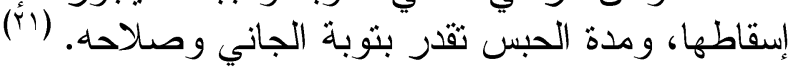

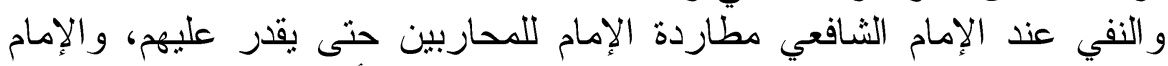

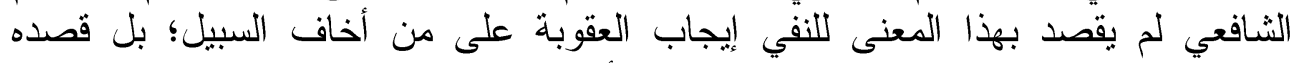

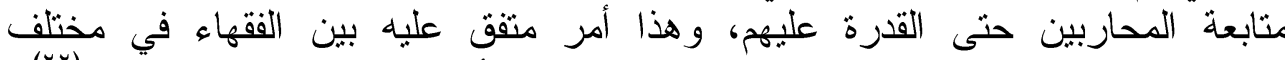

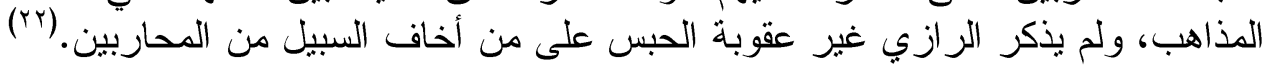


ونص الإمام الثافعي على حبس المحارب إذا لم يقترف الجريمة الموجبة للقتل

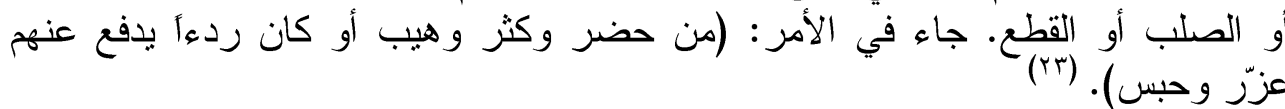
وقال الماوردي في معنى النفي: (النفي أن يطلبو الإقامة الحدود عليهم فبعدو ا)، و هذا قول

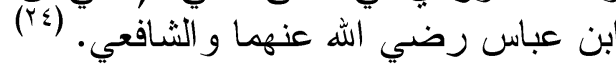

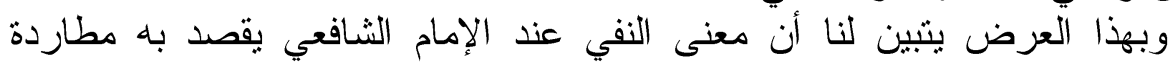

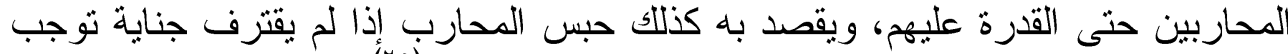

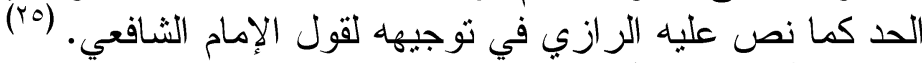

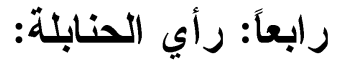

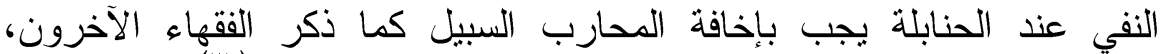

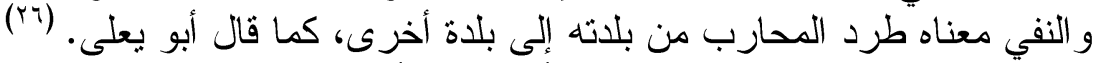

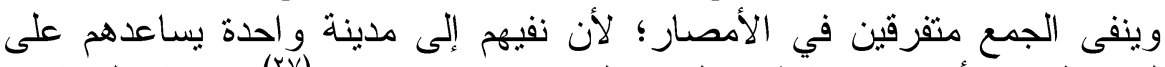

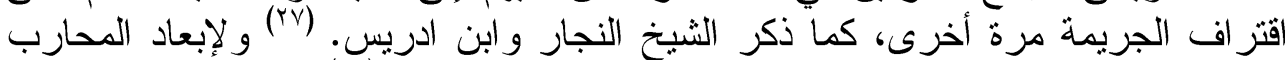

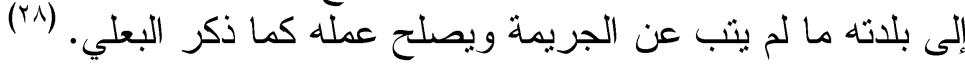

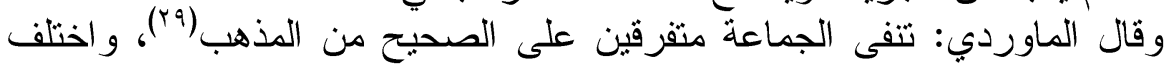

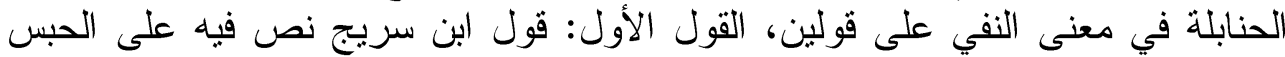

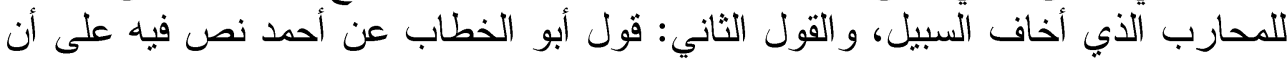

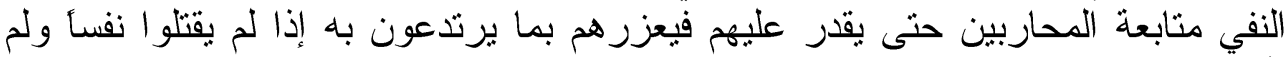

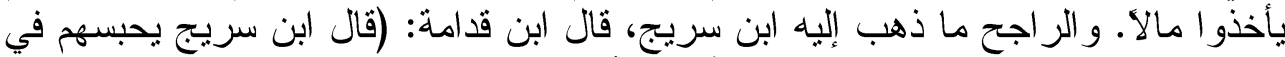

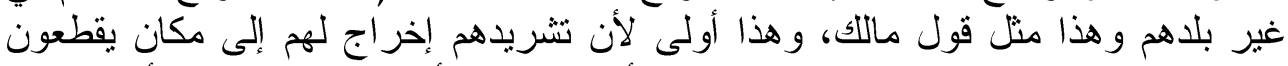

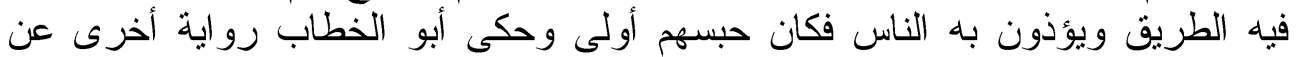

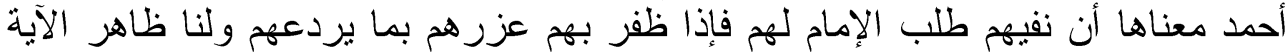

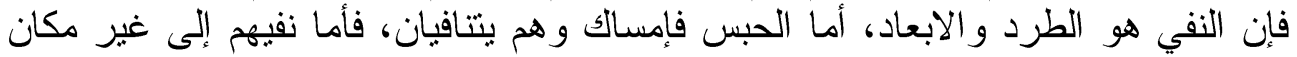

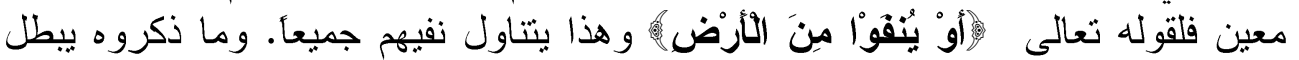

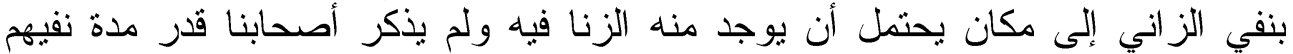

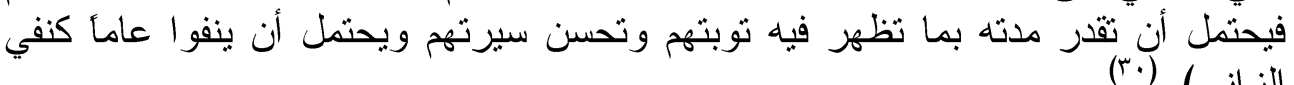

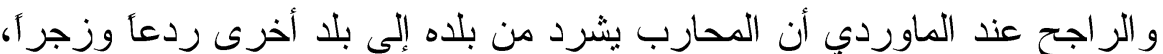

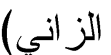

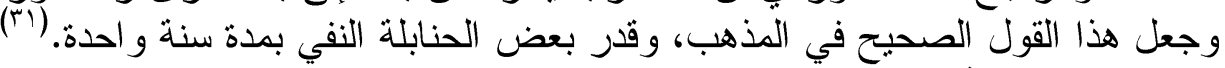

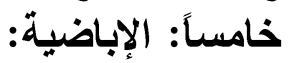
الزاجح عند الإباضية أن النفي هو الحبس.

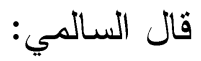

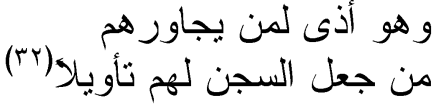

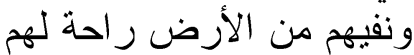
وعمر الفاروق كـــــان أو لا لاه

سادساً: واختلفت رواية الثيعة في معنى النفي.

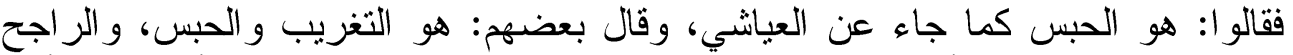
عند صاحب الجواهر أن النفي هو التغريب دون الحب؛؛ إلا إنه انشترط أن يقاطع أهل 


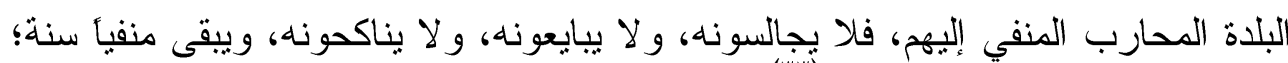

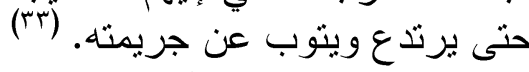
وكان الإمام علي رضي ربي الله عنه ينفي المفسدين من الكوفة إلى البصرة؛ ردعأ

وزجر أ كما ذكر الطباطبائي.

وقال الحلبي: (ينفى المحارب عن بلده ويكتب إلى وكلى ولى بلد يأوي إليه من مؤاكلته

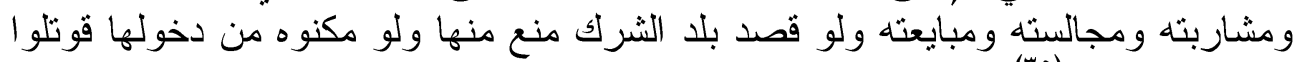

حتى يخرجوه). (ro)

\section{المطلب الثالث: عقوبة النفي في حد الزنا:}

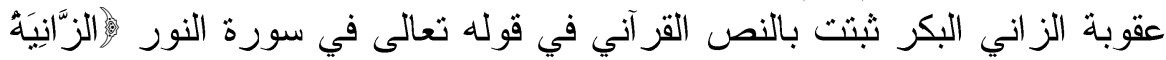

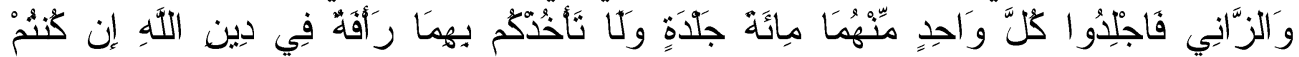

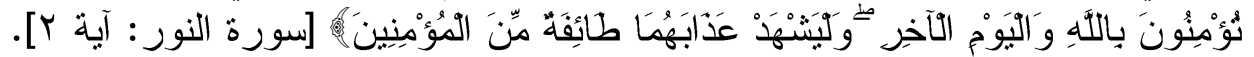

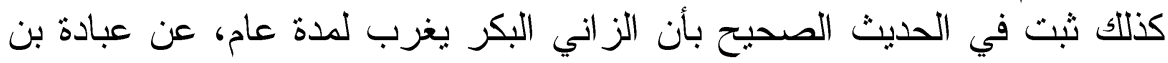

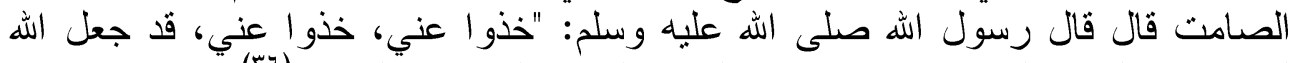

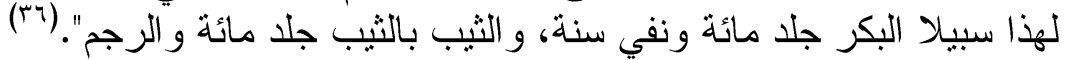

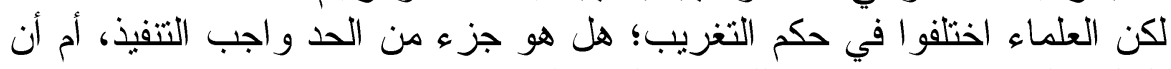

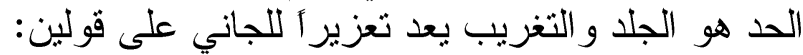

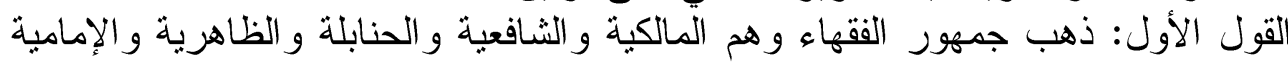

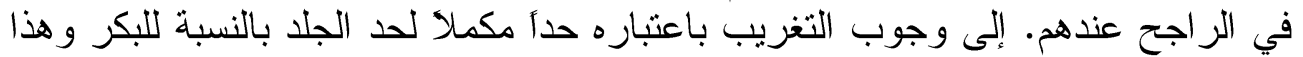

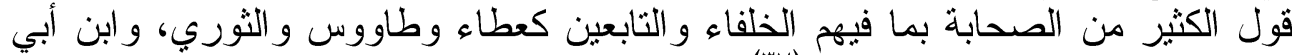

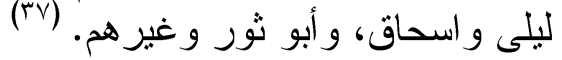

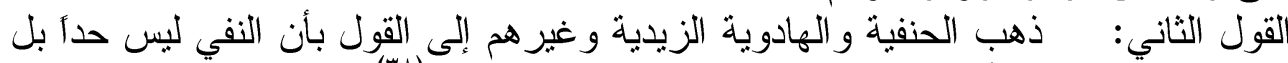

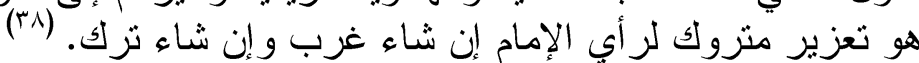

استدل أصحاب القول الأول وهم الجمهور على مذهبهم بما بلي:

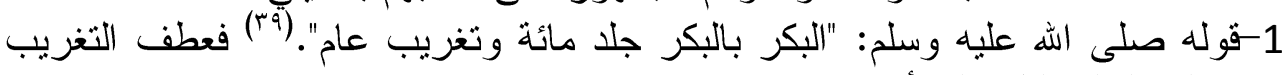

$$
\text { على الجلد دليل على أنه حد معه. }
$$

2-حديث العسيف حيث قال لله صلى الله عليه وسلم على ابنك "جلد مائة وتغريب

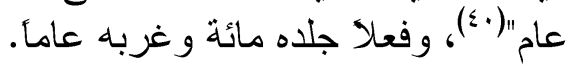

3-وفي نفس الحديث أن السائل قال: (سألت رجلا من عانداء أهل العلم فقالو ا إنما على ابنك جلد

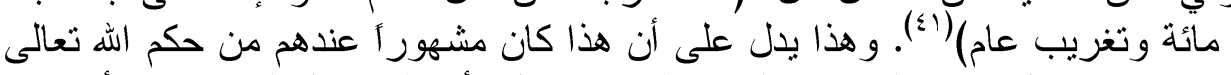

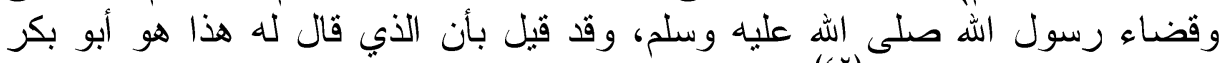

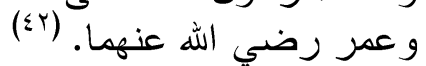

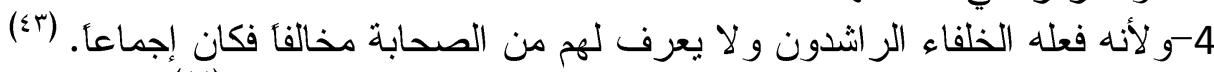

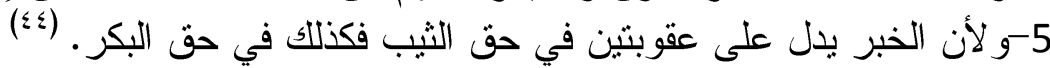

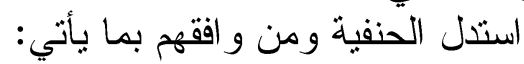

أدلة القول الثناني: الخئ

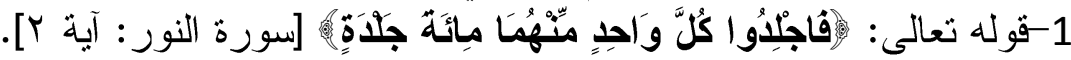

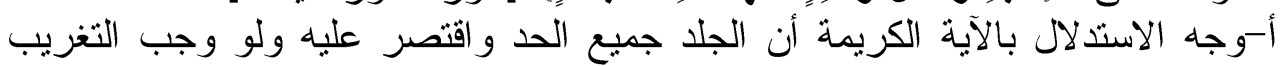

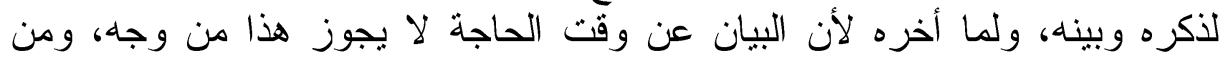


وجه آخر قالوا أن التغريب زيادة على النص و الزيادة على النص نسخ و القرآن لا ينسخ بخبر الآحاد.

ب-حكم النبي صلى الله عليه وسلم على سقيم وجد على بطن جارية يفجر بها فأمر

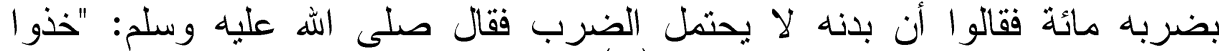

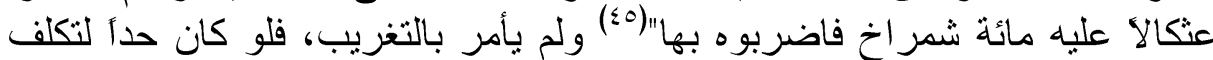

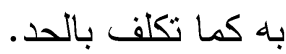

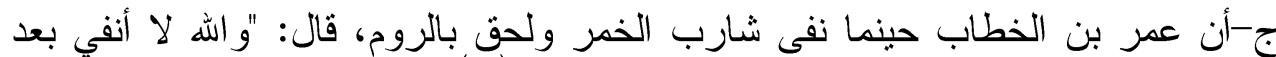

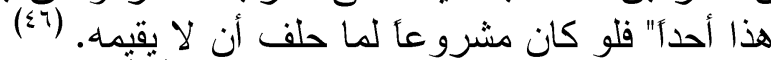

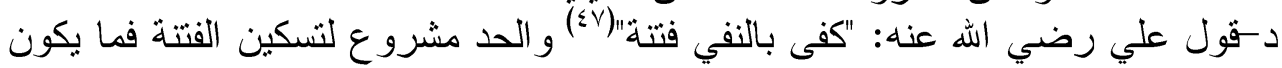

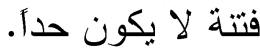
هـ-قالو ا أيضاً: إن كانت المغربة امر أة، يكون نفيها تعريضأ لها لمثل ما ابتليت به؛؛

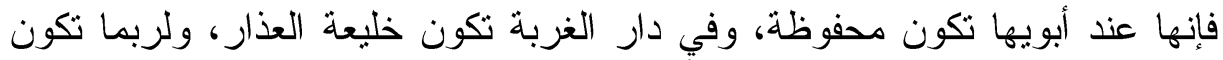

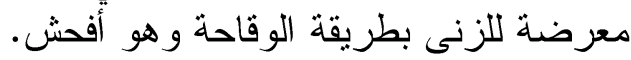

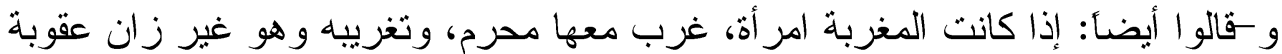

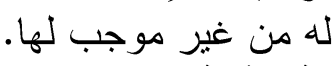

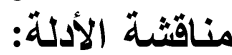
ناقش الحنفية أدلة الجمهور: قالو ا: أما الحديث فإن الجمع بين الجلد و التغريب كان في الابتداء، ثم نسخ بسورة

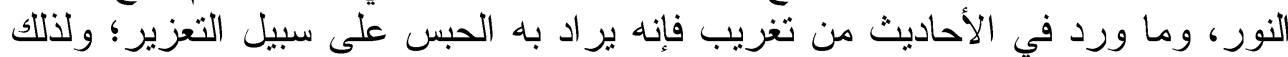

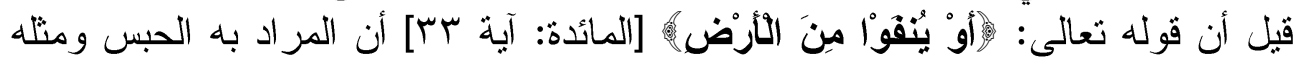

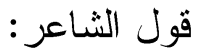
فإني وقيار بها لغريب أي محبوس

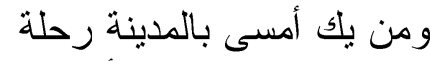

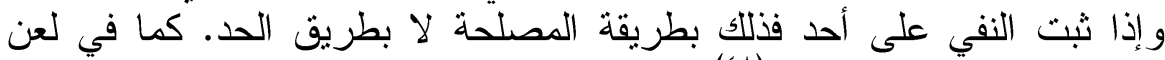

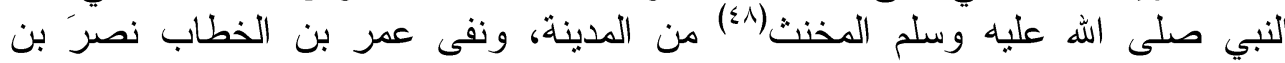
الحجاج من المدينة حين سمع قائلة تقول:

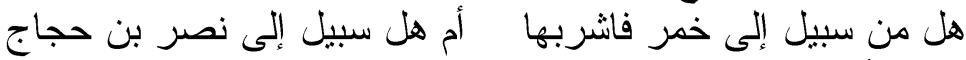

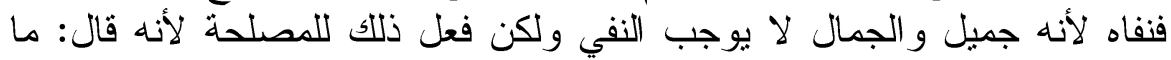

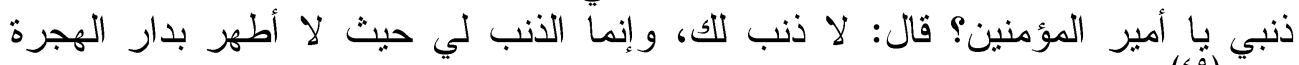

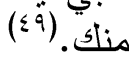

ناقش الجمهور أدلة الحنفية بقولهه:

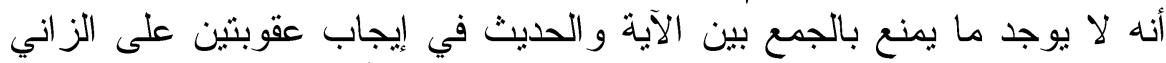

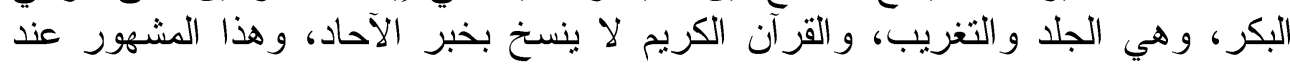

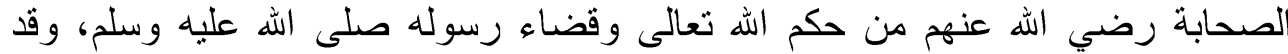

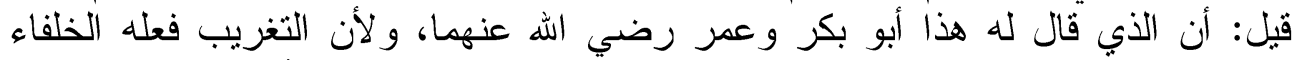

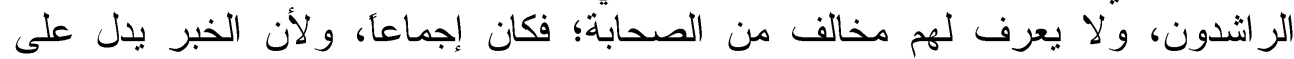

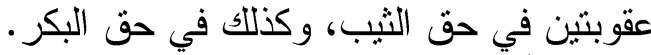

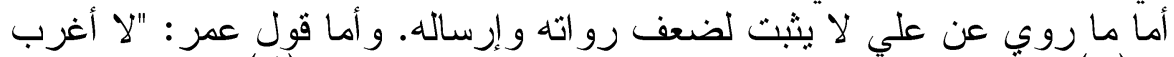

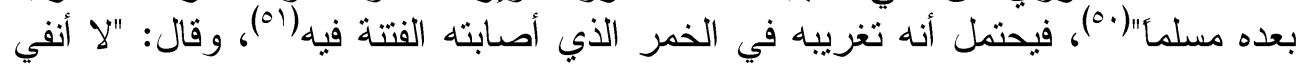


بعده أحدا" تعزيز أ لا حدأ؛ لأنه كان بسبب شربل شربه للخمر ، ومن المتفق عليه أن شرب الخمر

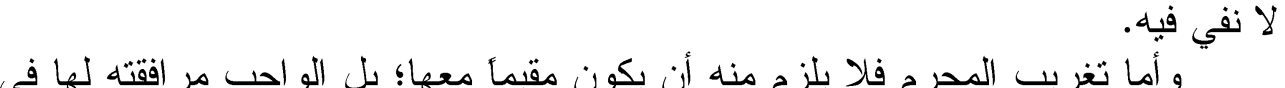

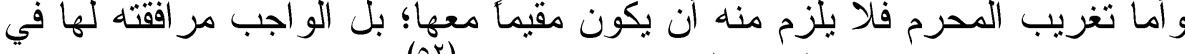

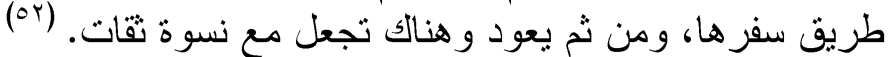

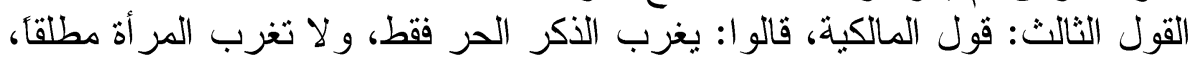

$$
\text { وبه قال الأوز اعي، و الر اجح في مذهب المالكية الأمامية. }
$$

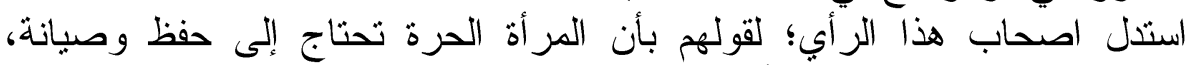

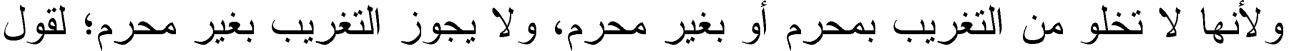

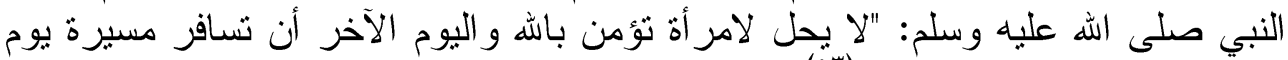

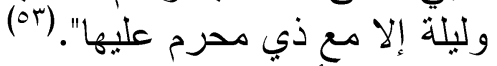
ولآن تغريبها بغير محرم إغراء لها على الفجور، وتضييع لها، وإن غربت

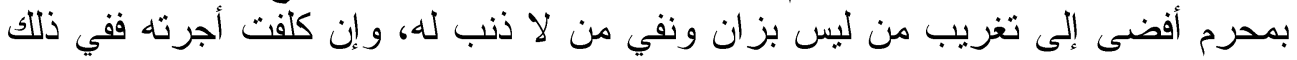

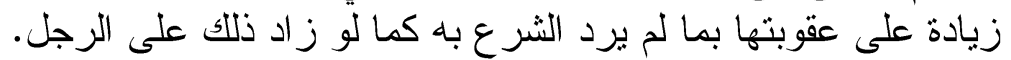

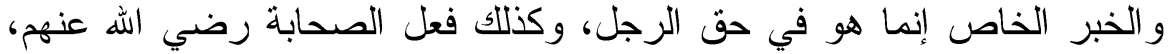

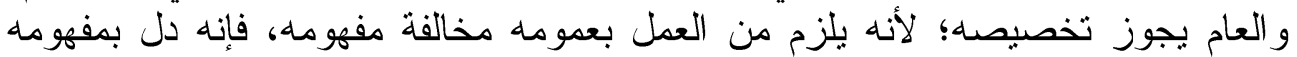

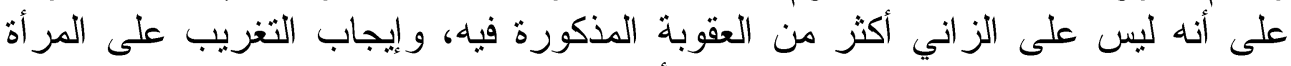

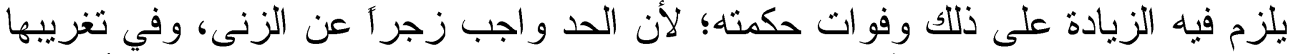
إغر اء به وتمكين منه؛ مب أنه قد يخصص في في حق الثيب بإسقاط الجلد في قول الأكثرين،

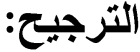

بعد استعر اض أقو ال العلماء في حكم التغريب للزاني المحصن؛ سواءً أكان ذكر أ

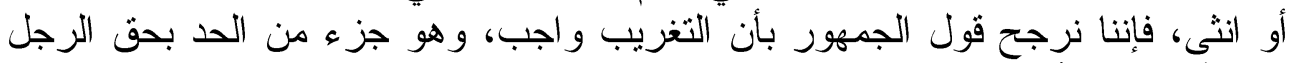

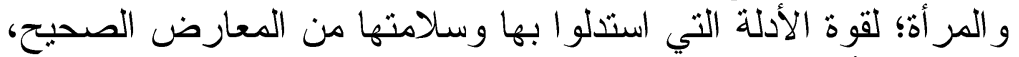

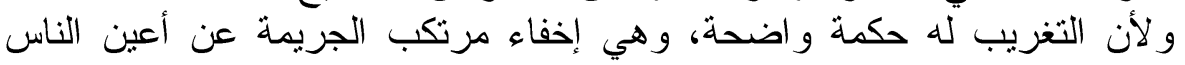

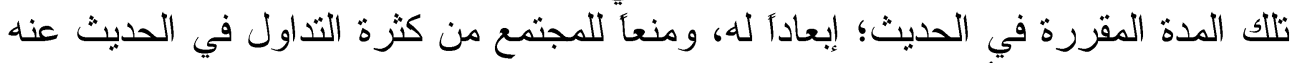

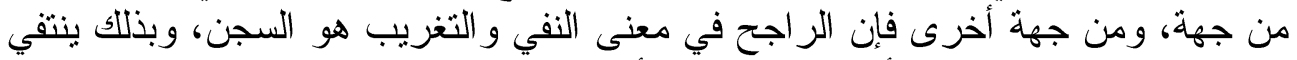

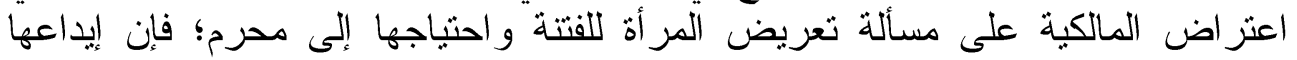

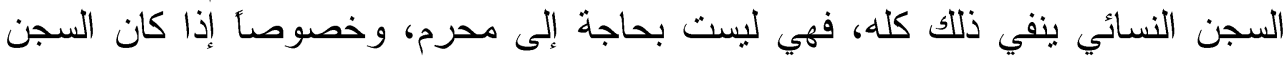

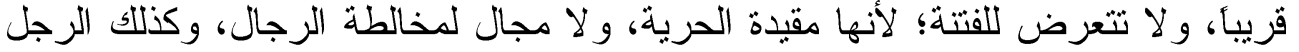

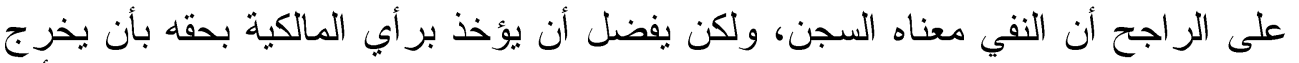
مسافة قصر، ويسجن في البلد الثاني، وبذللك يتحقق معنى النفي و التغريب وحكمة كف أذاه النّاه و عدم معاودته لازتكاب الجزيمة مرة فئه أخرى.

مسألة: مدة التغريب ومسافته:

اتفق الفقهاء على أن مدة التغريب سنة كاملة؛ وذللك للأحاديث الواردة في في ذللك،

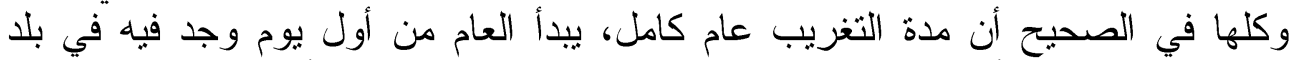

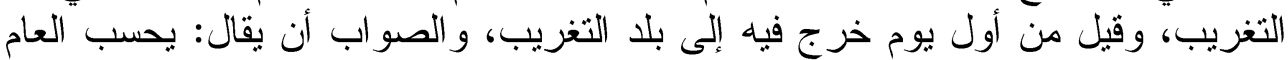

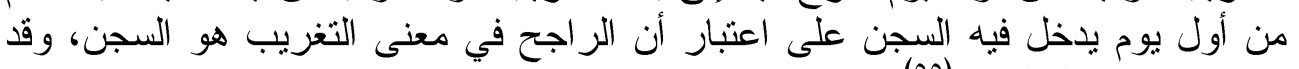

روي هذا عن المالكية. (00) فئن أما مسافة التغريب فقد اختلف القائلون بالتغريب فيها على أربعة أقو ال: 
الأول: يغرب الرجل و المر أة إلى مسافة القصر فما فوقها، وهي مرحلتان، وهذا قول

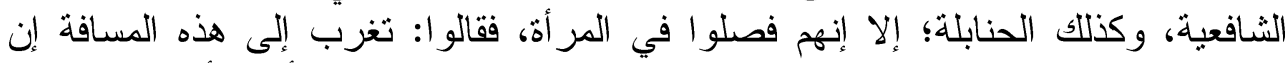

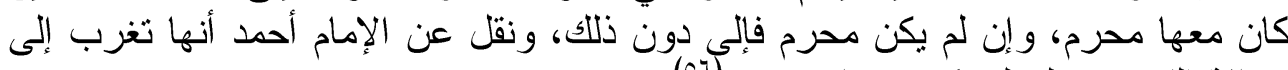

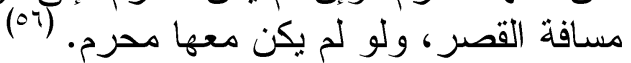

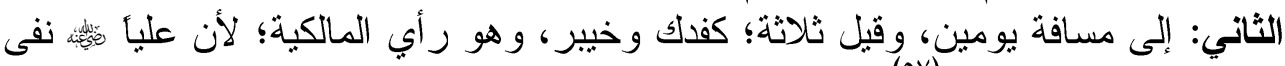

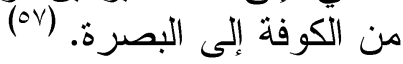

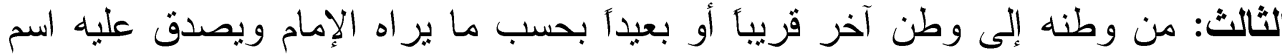

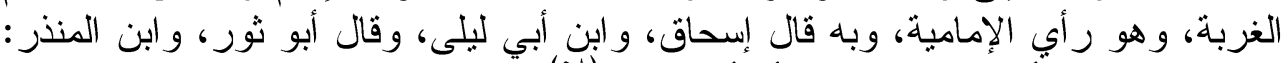

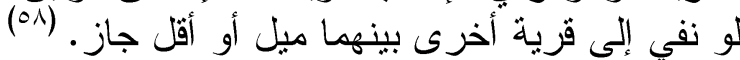
الرابع: ينفى من عمله إلى عمل آخر، وهي رواية لأحمد ينقلها الأثرم، وليس له حرية

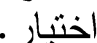

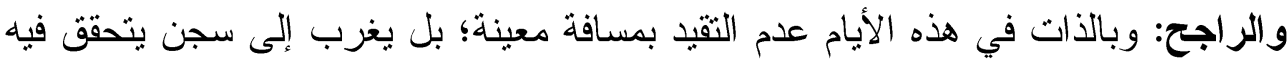

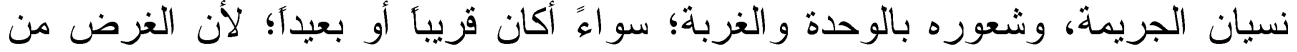

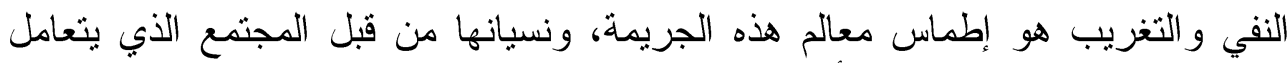
معه؛ بحيث لا يذكرونها كلما رأوها وليس له حرية اختيار المكان الذي يغرب إليه في قول الثافعية؛ لأن ذللك أليق

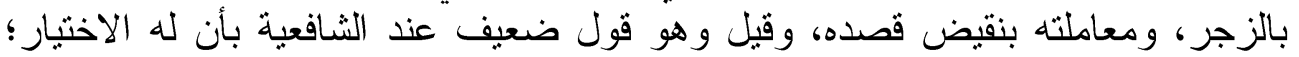
وذللك لأن المقصود بالتغريب إيحاثها بالبعد عن وطنه، و هذا يمكن أن بتحقق في أي وطن الأن كان. (09) وقال المالكية: لا يجوز إعطاؤه حرية الاختيار، حيث قالو ا: يخرج من بلده الذي

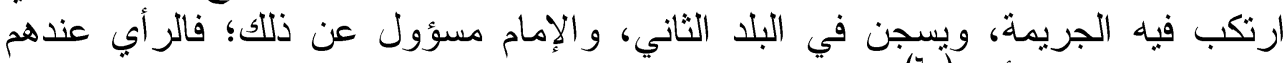

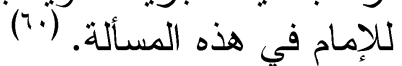

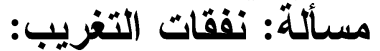
اللعلماء في هذه المسألة عدة أقو ال: الفيات

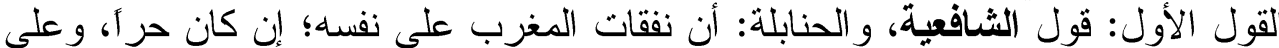

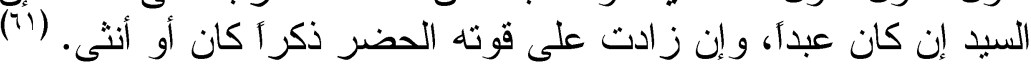

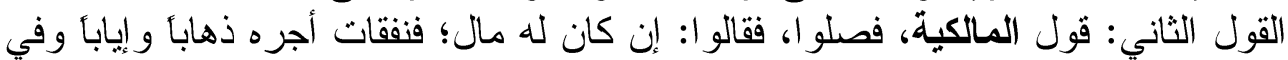

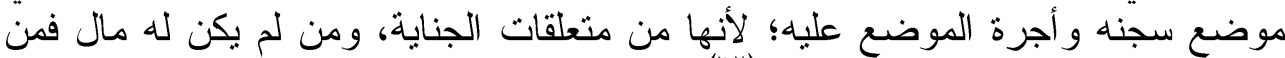

مال بيت المال؛ و إلا فعلى المسلمين. القول الثالث: في نفقات المحرم المغرب. قال بعض الثافعية: إنها على المر أة المغربة؛ لأنهم قاسو ا ذلك على سفر ها معهد

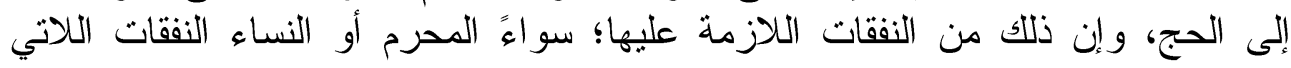
أما الحنابلة، فقالو ا: إن كان لها مال وجب من مالها، وإن لم يكن لها مال فلهر

$$
\text { يخرجن معها. }
$$

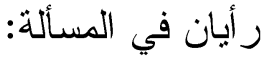

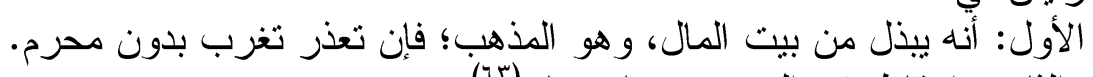

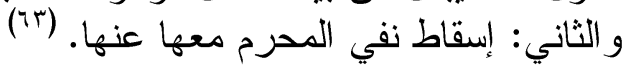


و الذي نر اه في هذه المسألة: بأن نفقات المغرب تكون في بيث المال؛ لأن ذلك الكان

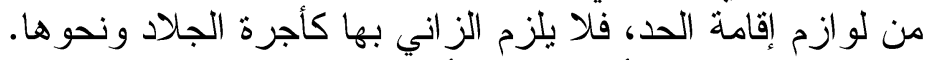

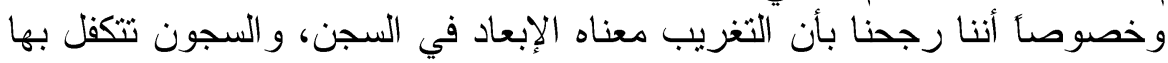

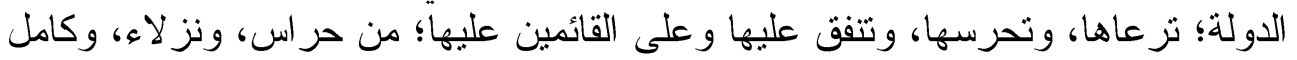
تجهيز اتها ولو ازمها وما، ومتطلباتها.

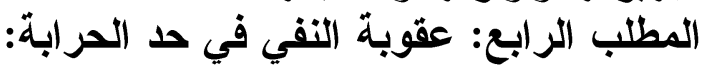

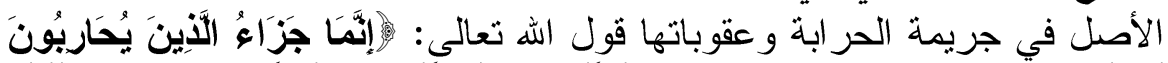

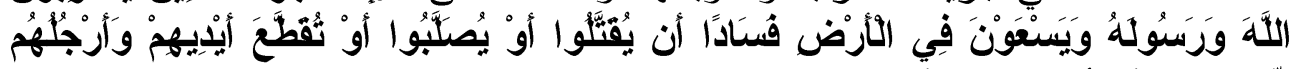

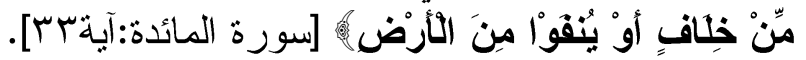

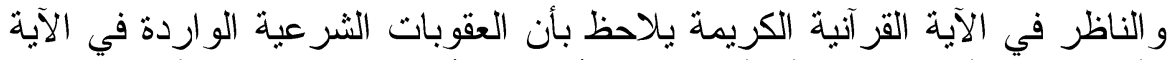

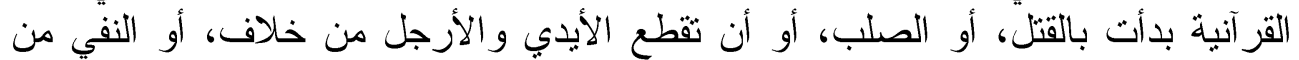

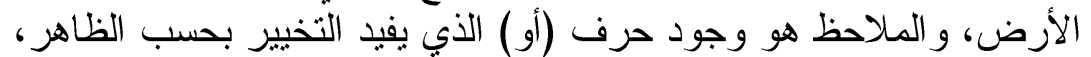

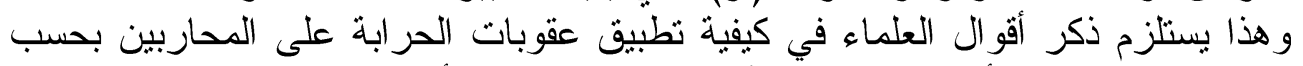

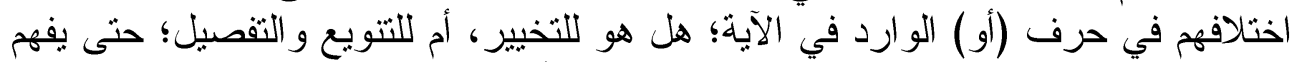

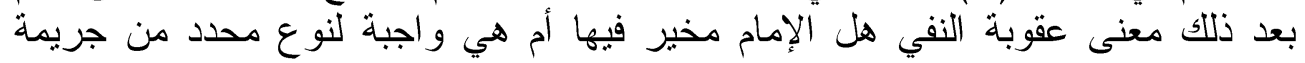
الحر ابة؟

\section{اختلف العلماء في ذلتك على قولين:}

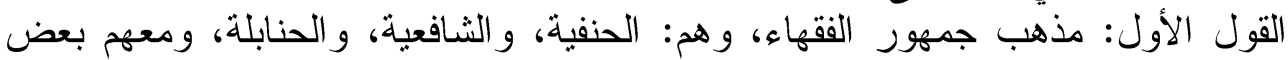

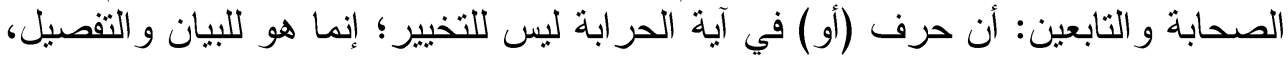

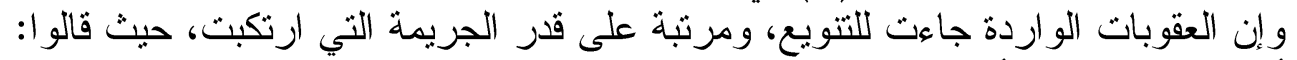

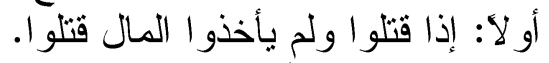

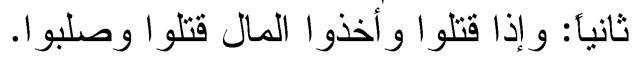

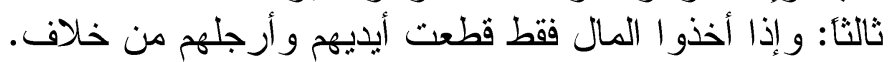

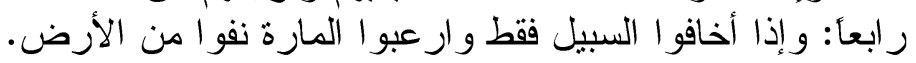

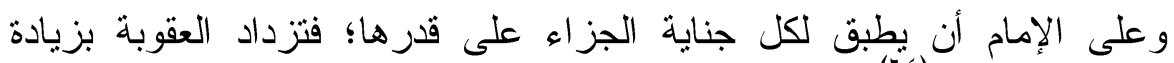

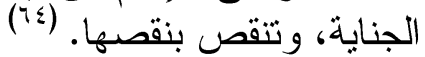

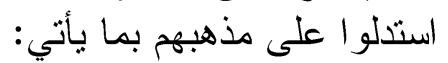

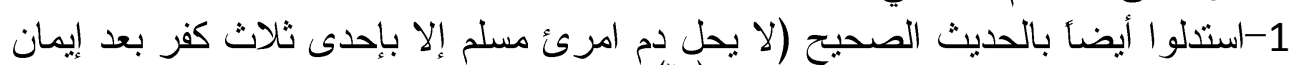
وزنأ بعد إحصان وقتل نفس بغير نفس). (70)

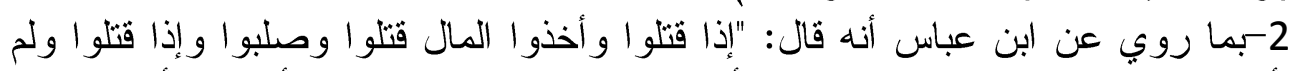

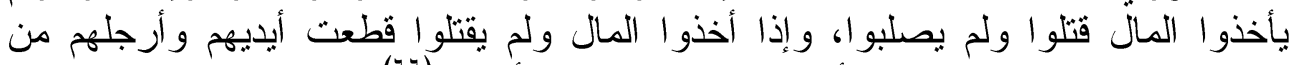

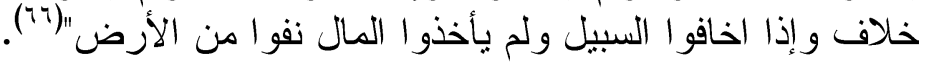

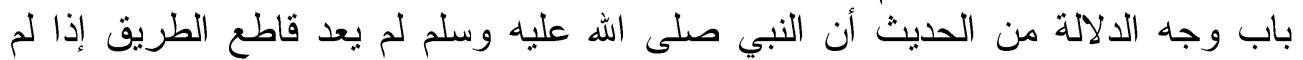

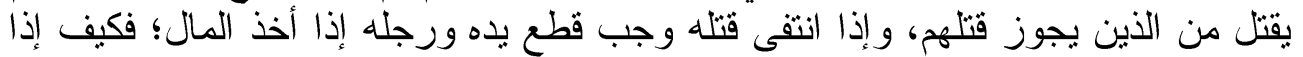

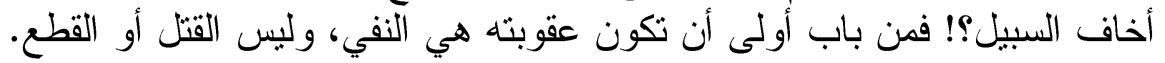

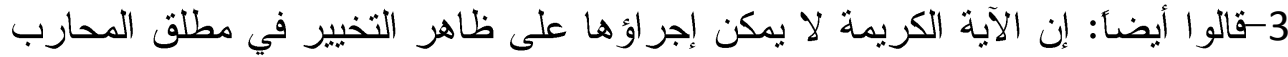
لأمرين: الأول: إن العقل بقتضي أن يكون الجزاء مناسبأ للجناية يزداد بازديادها، وينقص بنقصها،

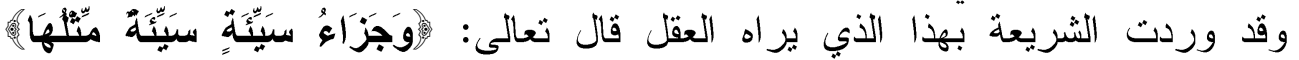


[الثورى: آية •ـ؛] فالتحير في جزاء الجناية القاصرة بما يشمل جزاء الجناية الكاملة وفي

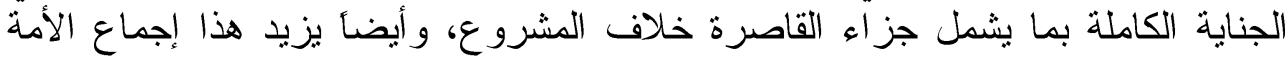

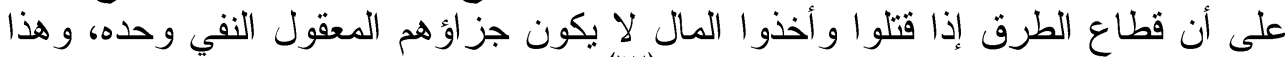

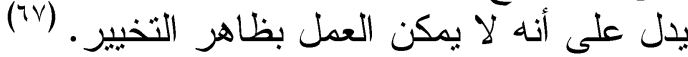

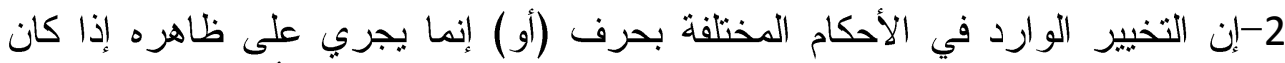

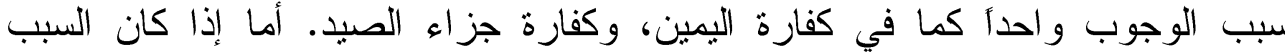

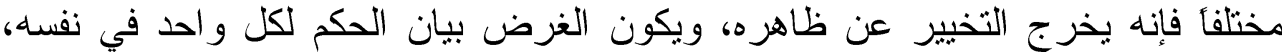

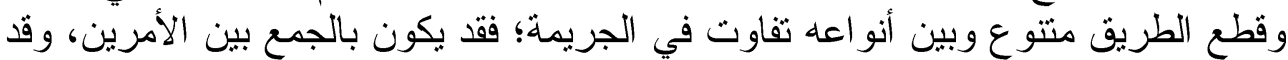

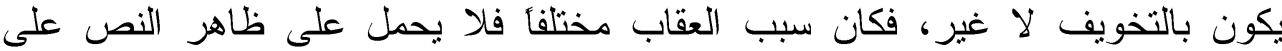

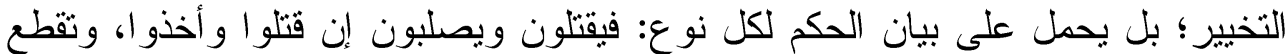

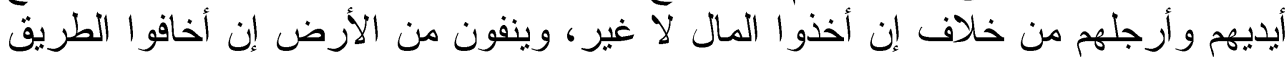

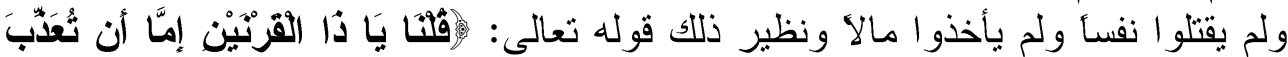

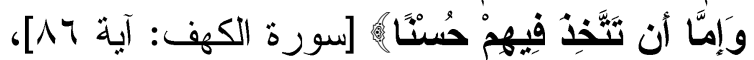

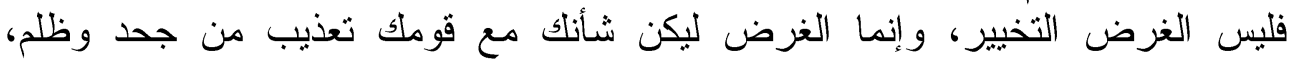
و الإحسان إلى من آمن وعمل صالحأ، فلما اختلف السبب حملت الآية على بيان الحكم لكل

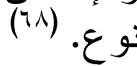

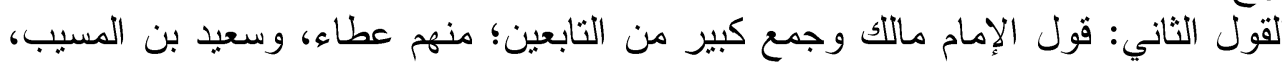

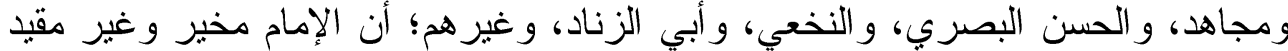

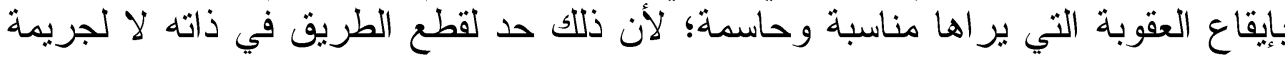

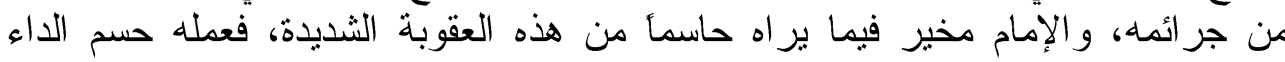
وليس الداء في نوع دون نوع، إنما في قطع الطريق ذاتها، وبهذا فال الظاهرية

$$
\text { و الثيعة. }
$$

$$
\text { و واستذل أصحاب هذا القول بما يلي: }
$$

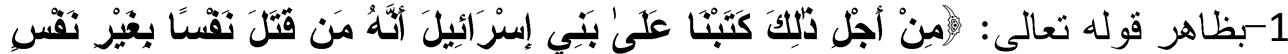

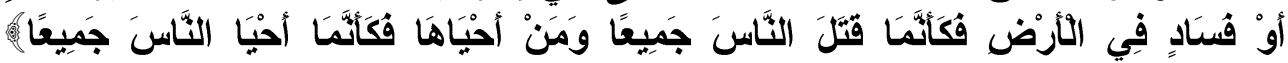

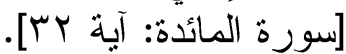
وجه الدلالة في الآية الكريمة: أنها بينت أن الفساد في الأرض بمنزلة قتل النفس في باب

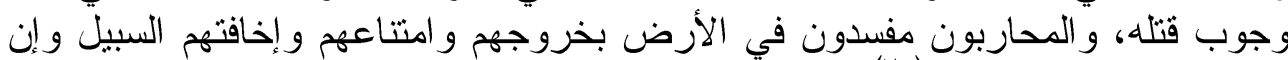

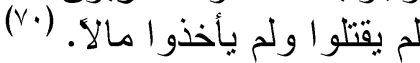
2-استنلو القول ابن عباس رضي الله عنهما "ما كان في القرآن بلفظ أو فصاحبه

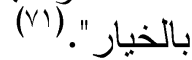
3-إن الله تعالى ذكر هذه الأجزية بكلمة (أو) وهي موضوعة للتخيير، كما في كفارة

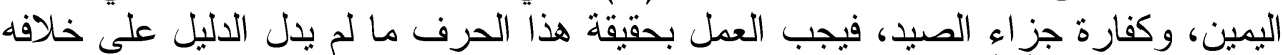

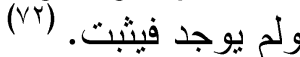

وقد ناقش أصحاب القول الثاني أدلة الفريق الأول، وقالو ا: إن احتجاجهم بحديث

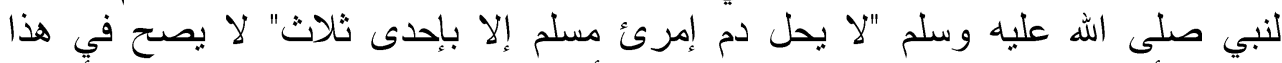
المقام؛ لأن الحر ابة نوع من الاعتداء على الأمة من داخلها، والحديث مقيد بالأحو ال لال 


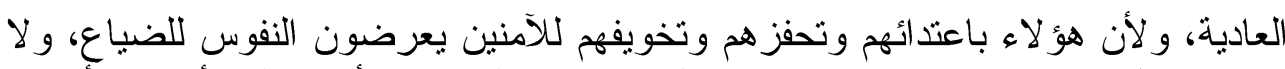

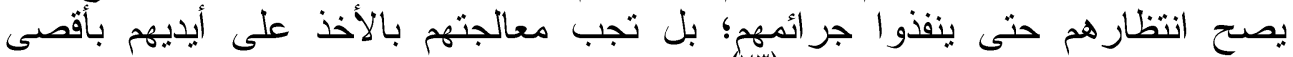

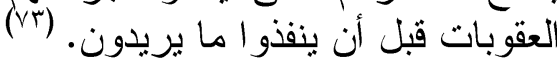

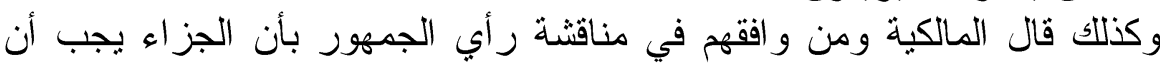

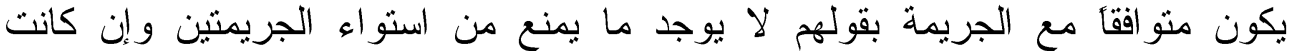

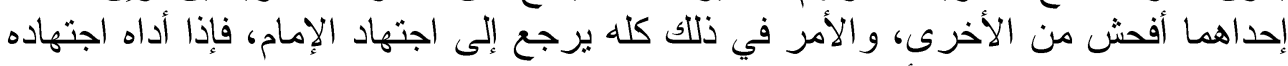

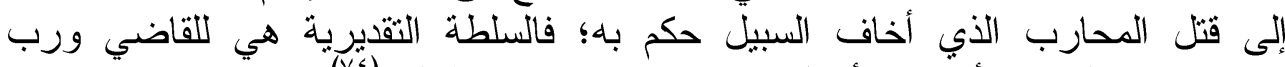

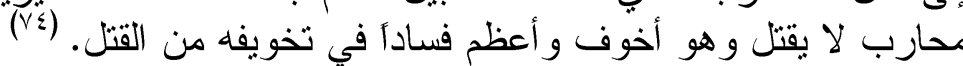

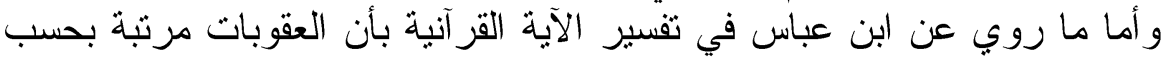

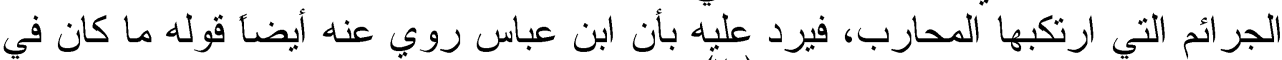

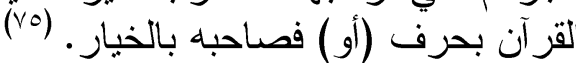
وبعد عرض الأقوال و المناقشة، لأبد من الإشارة إلى ألى المالى المالكية و الظاهرية وهم

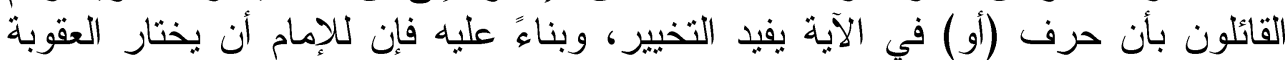

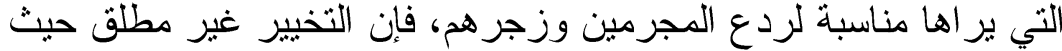

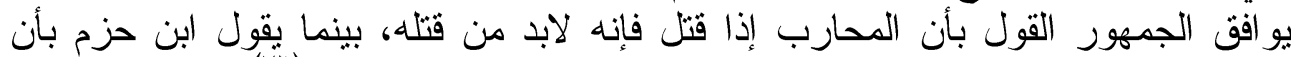

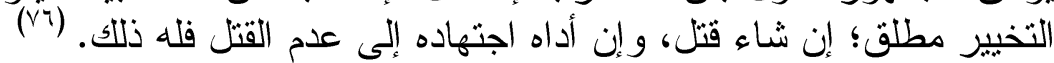

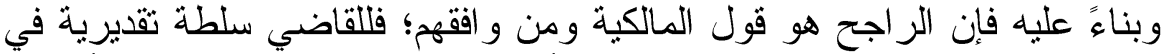

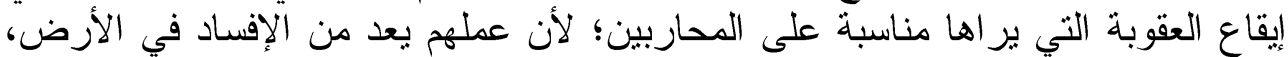

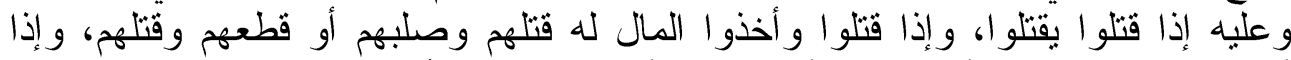

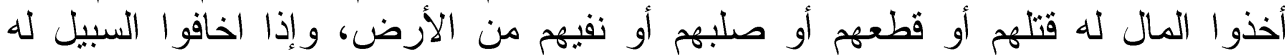

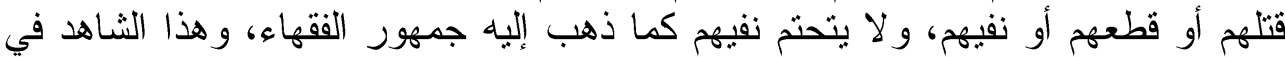
موضو عنا الذي نحن بصدد بحثه ومناقشته بأنه لا يتحنت النفي في حالة إخافة السبيل فقط

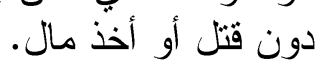

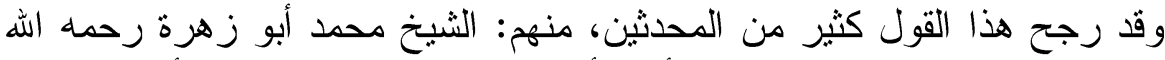

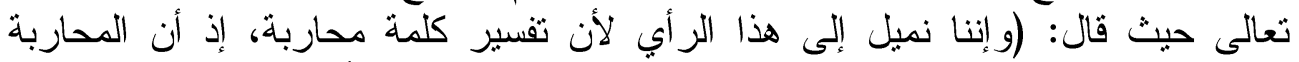

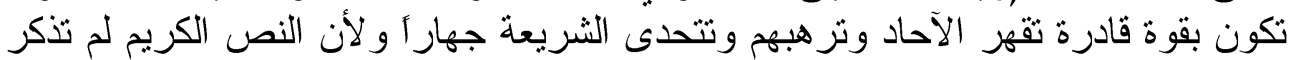

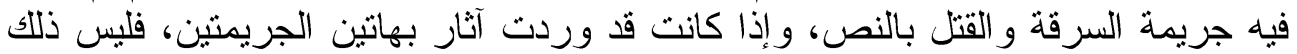

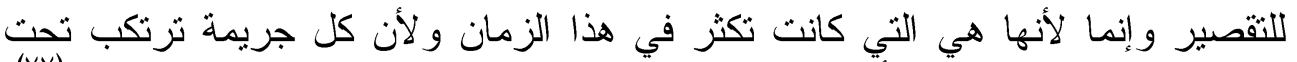

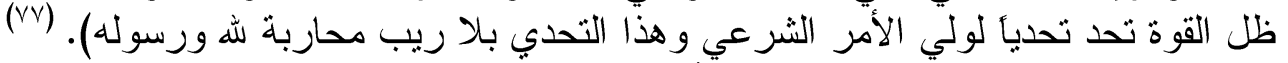
ورجح القول بالتخيير الإمام الأكبر محمود شلتوت، حيث ثال في كتابه الإسلام

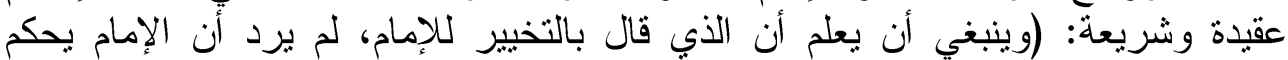

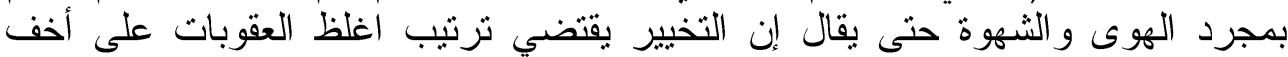

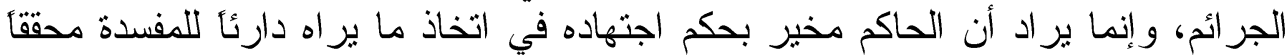

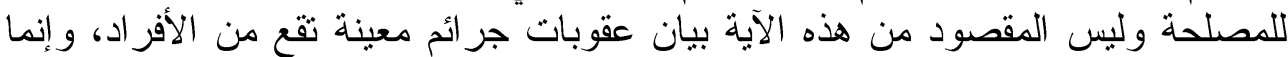

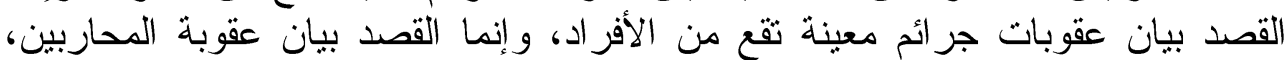

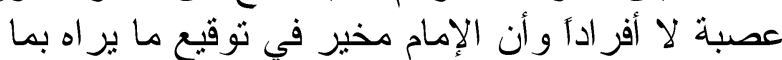

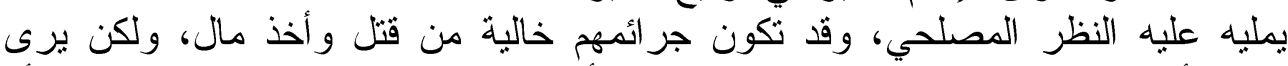

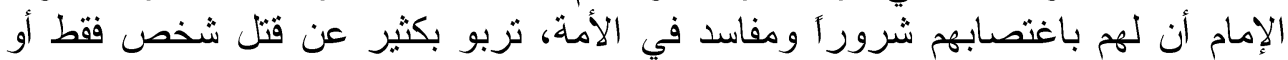

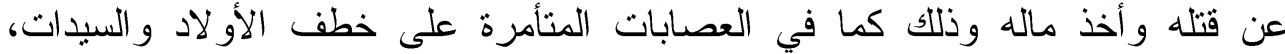

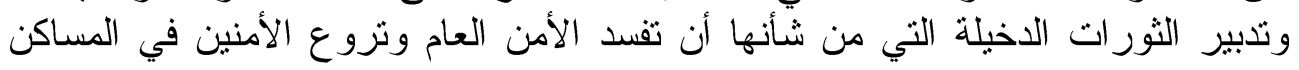


و الطرقات و لا شك أن هذا التخيير هو أساس صلاحية هذه الآية لأن تكون مصدر ألأعظم تشريع يضرب به على أبدي العصابات المفسدة).

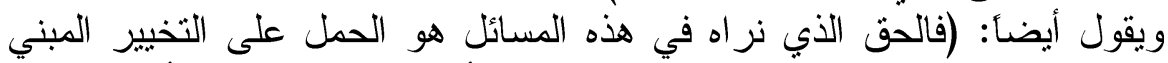

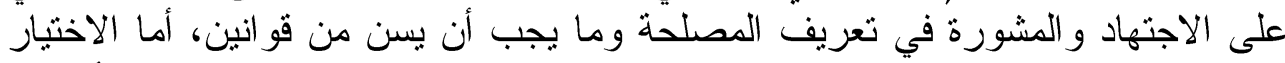

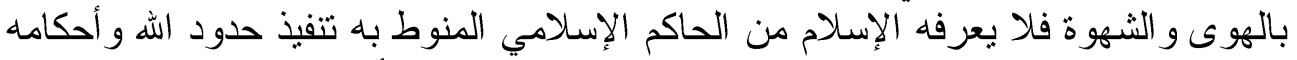
ورجح القول بالتخيير من المفسرين المحدثين الشيخ محمد الأمين الشنقيطي في تقسيره

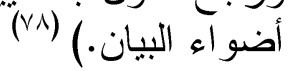

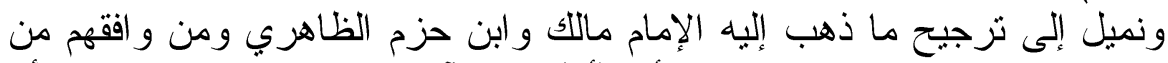

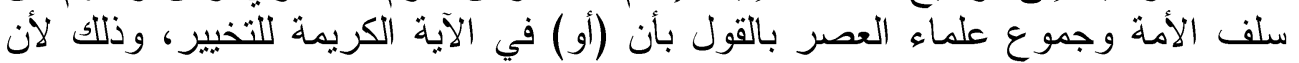

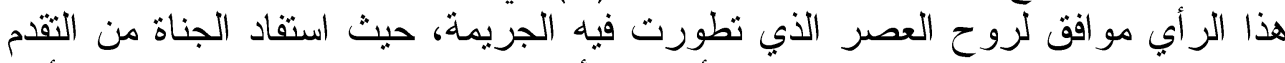

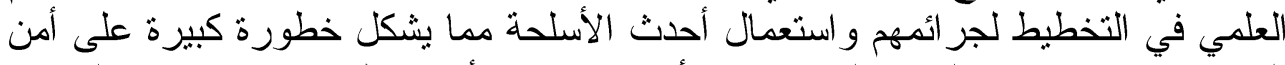

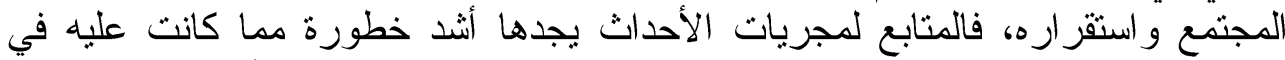

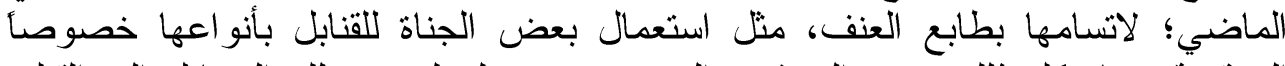

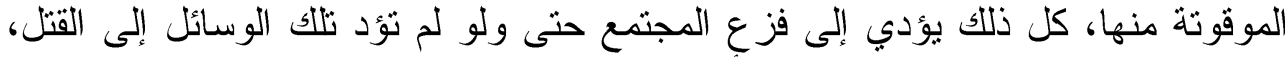

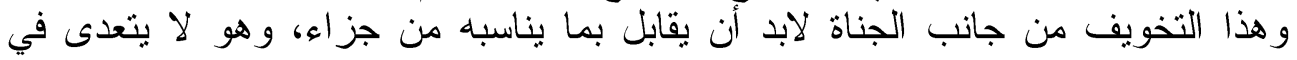

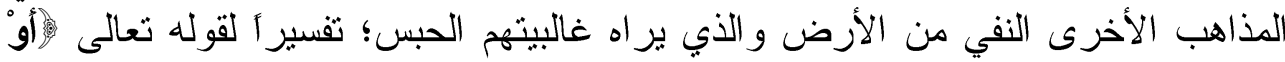

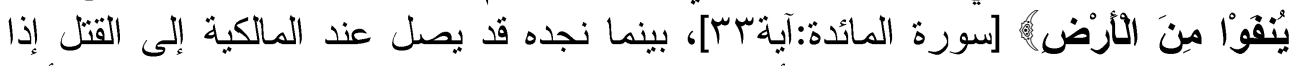

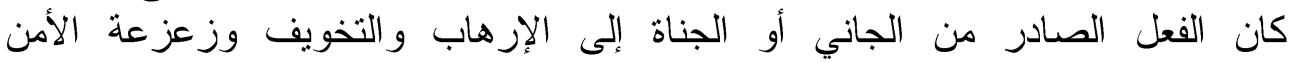

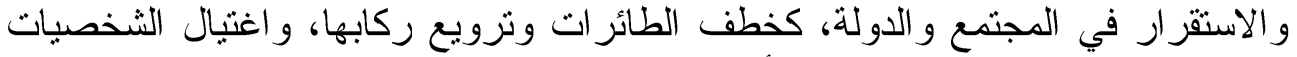

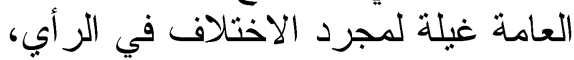

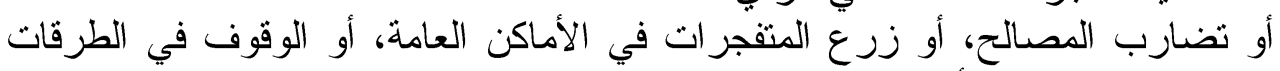

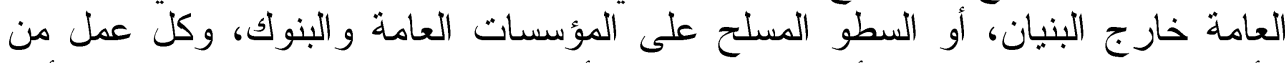

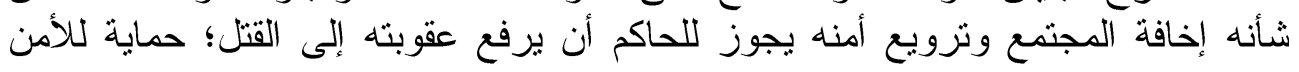

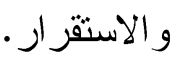

وقد ذكر الثافعية في فقههم بأنه رب خوف أنثد من الموت، وعليه تستوي

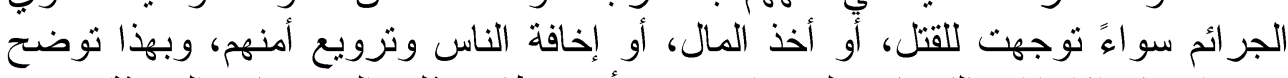

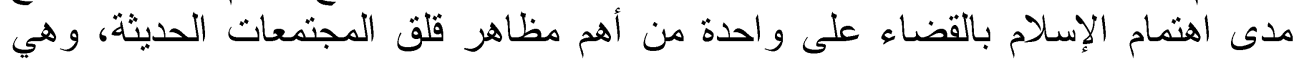

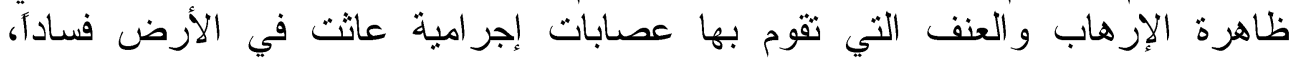

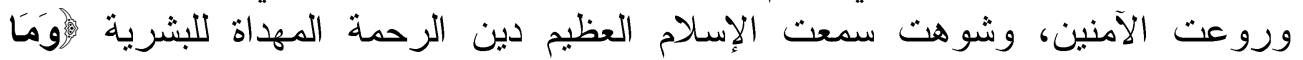

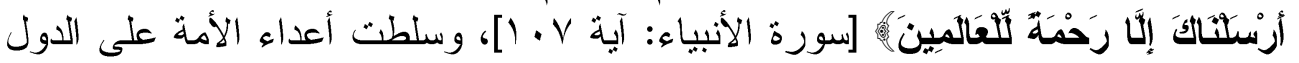

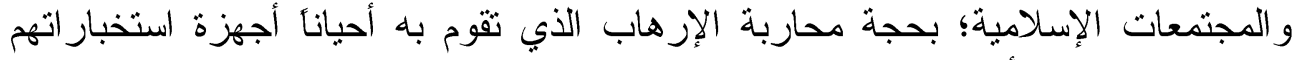

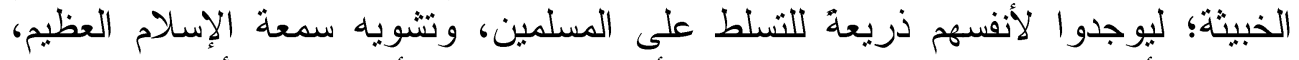

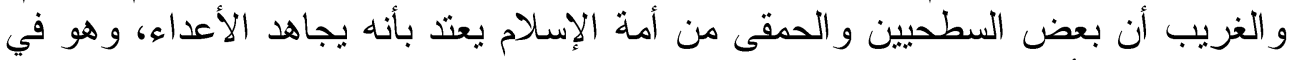

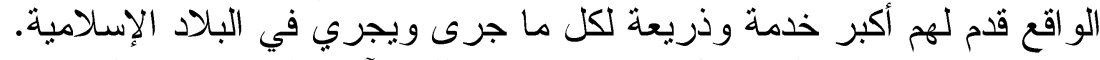

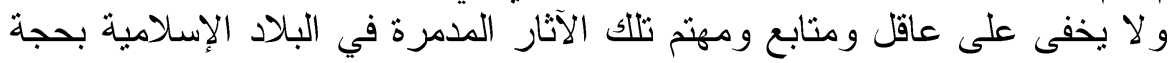

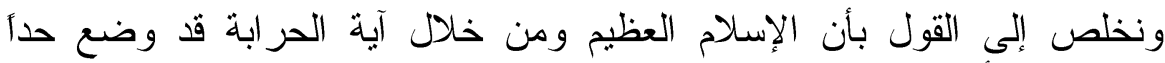

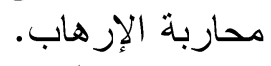
لقضية تؤرق العالم بأسره، وهي قضية الإرهاب سواء في نعريف الإرهاب و الجر ائم التي لحي 
يرتكبها الإرهابيون، أو في العقوبات الر ادعة لهم جزاء أعمالهم التي يروعون فيها أمن

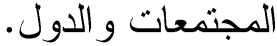

و الله أعلم وكذلك رجح التخيير مجلس هيئة كبار العلماء في المملكة العربية

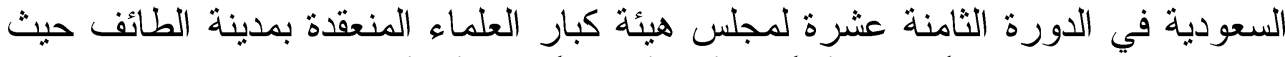

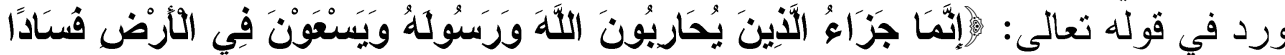

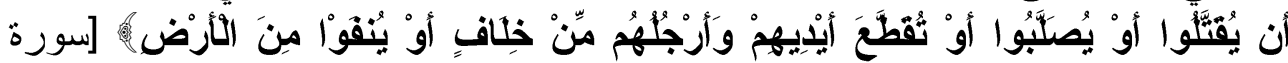

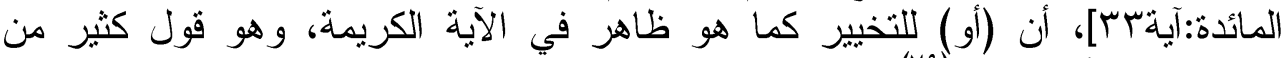
المحققين من أهل العلم. (va)

المطلب الخامس: عقوبة النفي في الجرائم التعزيرية وتطبيقاتها المعاصرة: وفيه المسائل التالية:

\section{المسألة الأولى: مشروعية النفي تعزيراً.}

لا خلاف بين العلماء في مشروعية معزية النفي كعقوبة تعزيرية يقدرها الإمام، و الأدلة

على ذللك كثيرة ومستفيضة، منها:

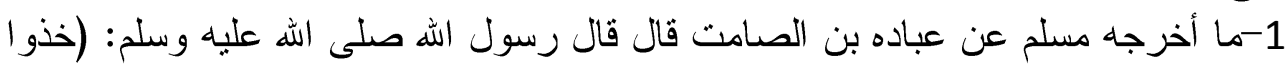

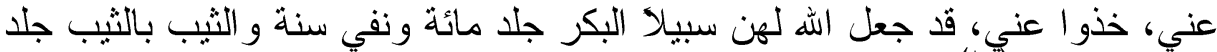

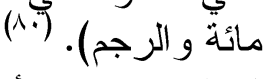

2-قال البخاري نفي أهل المعاصي و المخنثين: وساق حديث ابن عباس رضي الله عنهما

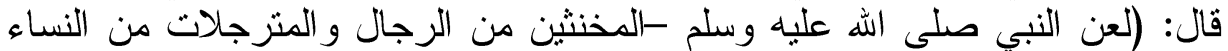

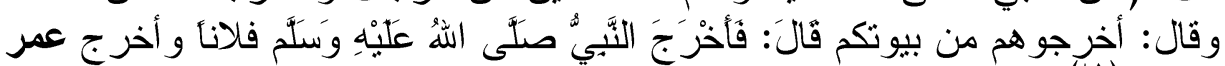

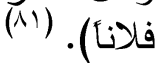

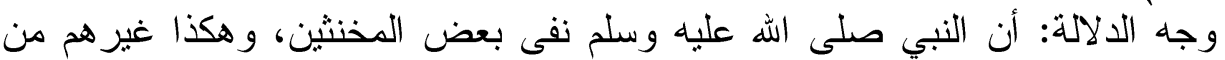

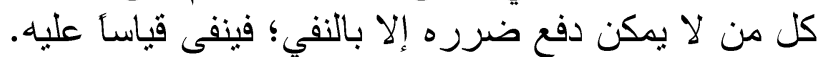

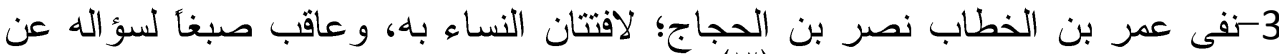

الذاريات و المرسلات وسبهـهن.

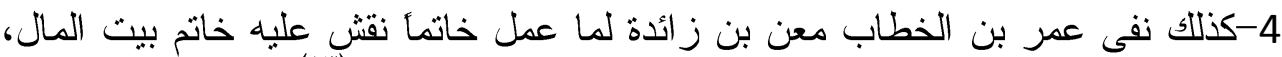

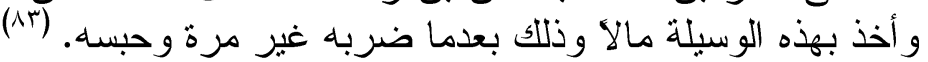

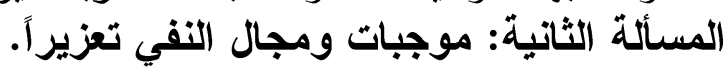

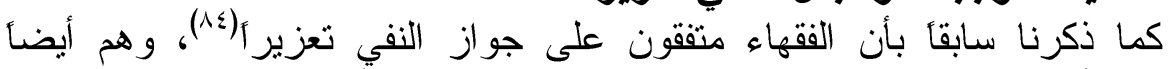

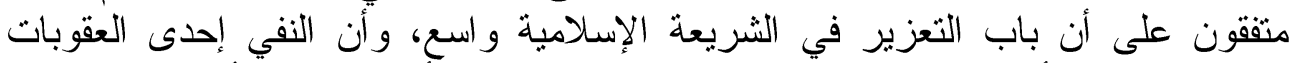

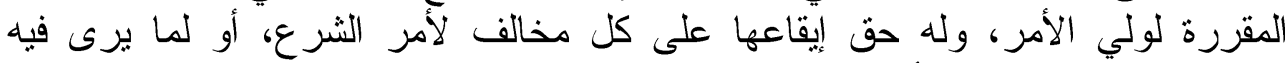
المصلحة للمسلمين، ومن أمثلة ذلك: الكئ

1-نفي المخنث وغيره ممن بخرجون على تلى تعاليم الإسلام و أوامره ويظهرون مظاهر

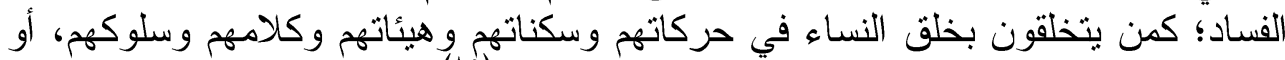

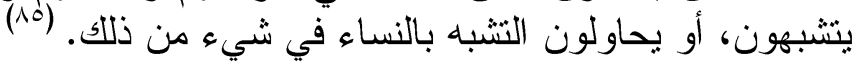

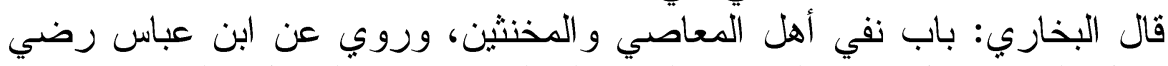

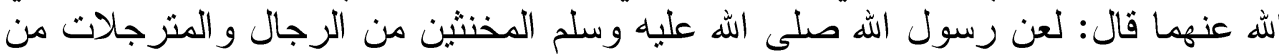

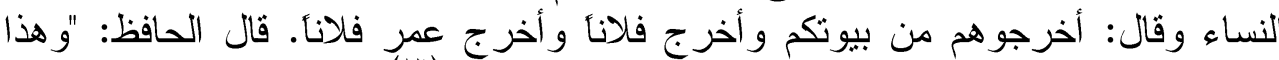

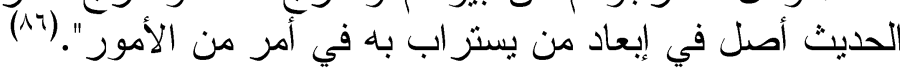




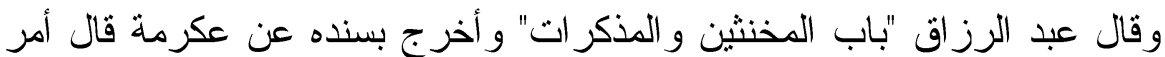

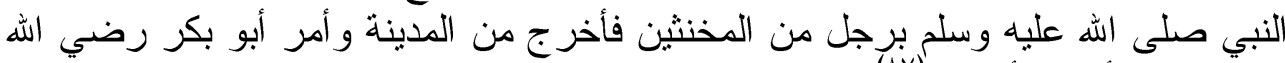

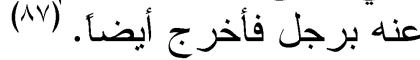

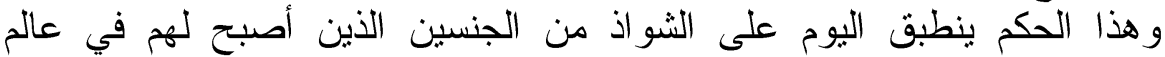

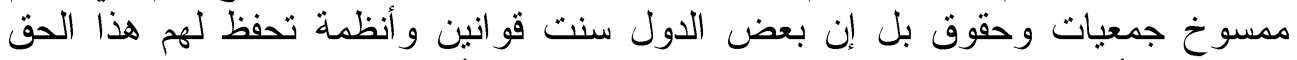

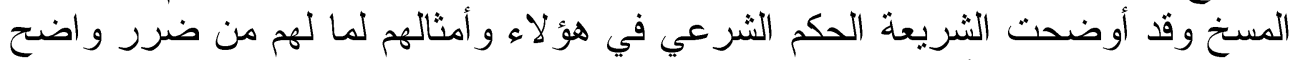
على المجتمع المسلم و أخلاقه الكريمة.

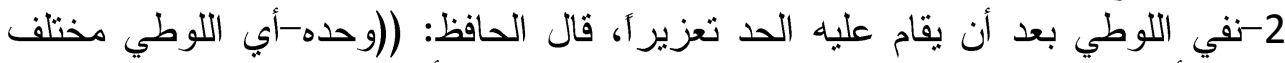

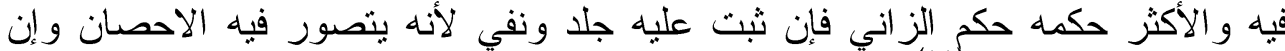

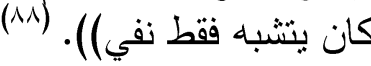

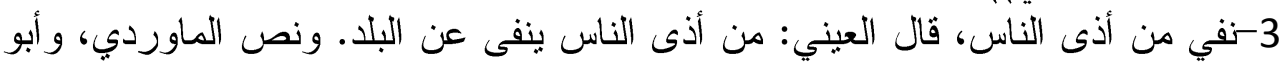

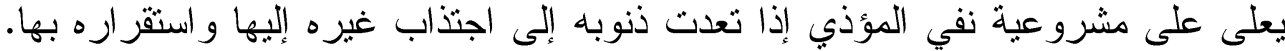

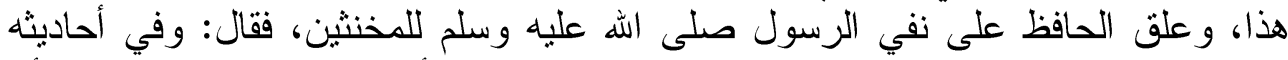

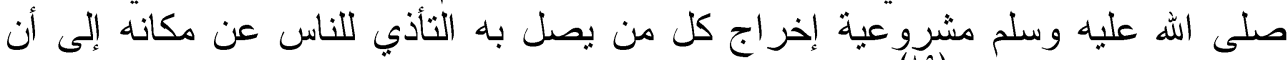

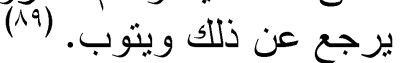
4-نفي شارب الخمر إذا اقتزف جريمته بظروف مغلظة؛ كما لو تتاول الخمر في نهار

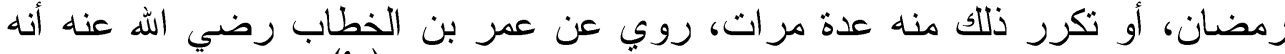

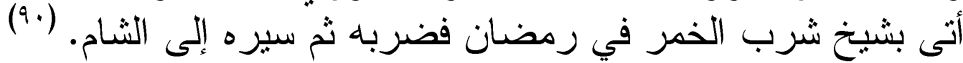

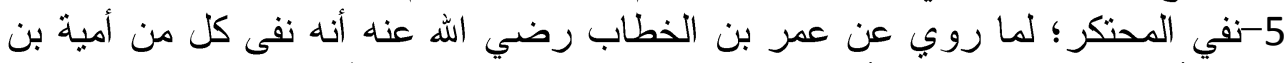

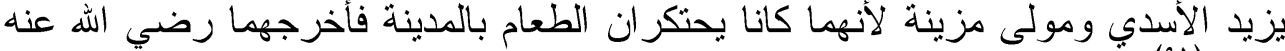

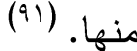

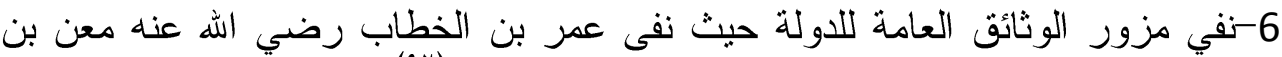

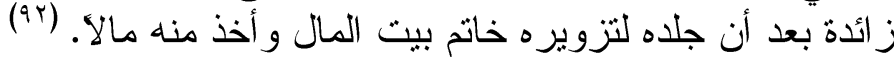

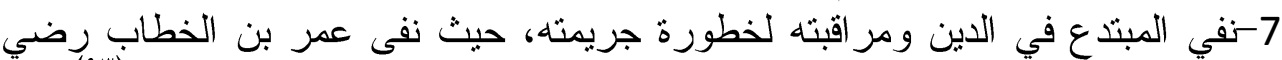

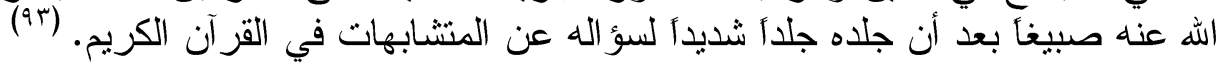

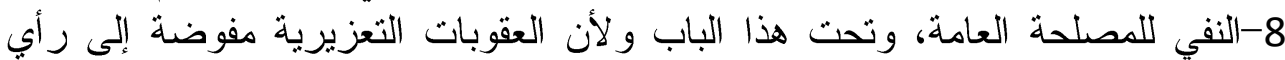

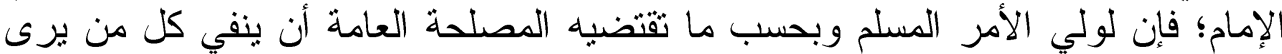

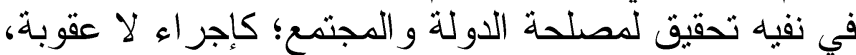

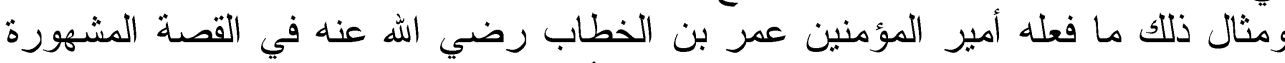

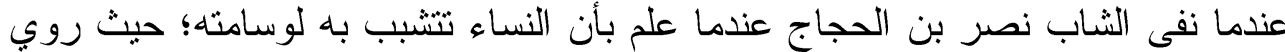

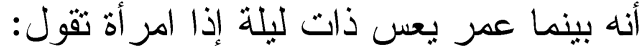

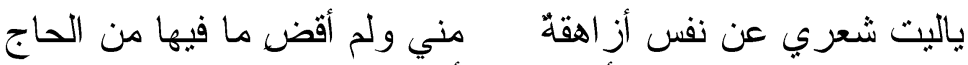

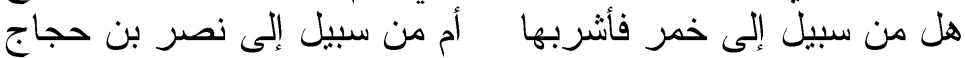

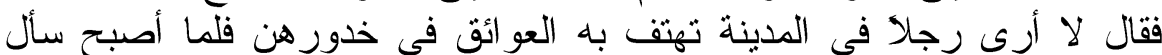

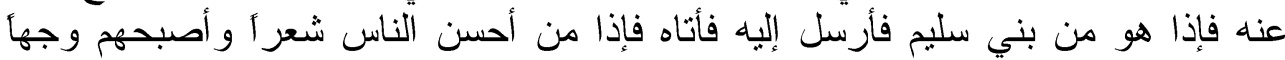

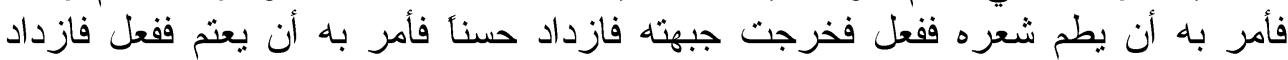


حسنأ فقال عمر : "لا و الذي نفسي بيده لا تجامعني بأرض أنا بها" فأمر بما يصلحه وسيره

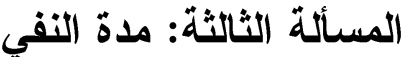

وفيه النقاط التالية:

1-مدة النفي في حد الزنا ثابتة في الأحاديث الصحيحة عن رسول الله صلى الله عليه

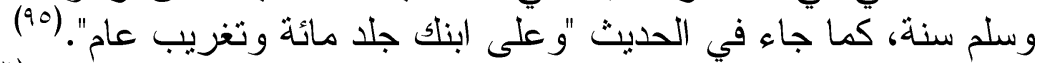

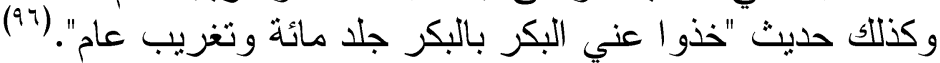

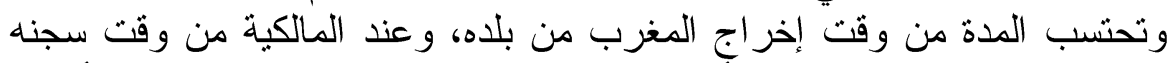

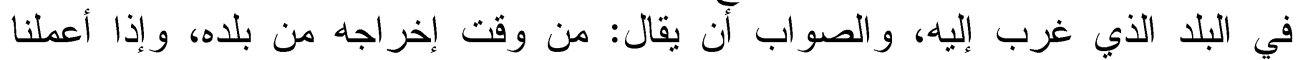
الر اجح من أقو ال العلماء؛ فأن المقصود بالنفي: هو السجن، ويكون من تاريخ إيداعه السهن

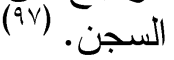

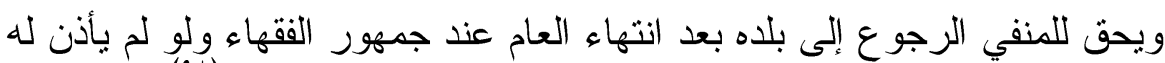

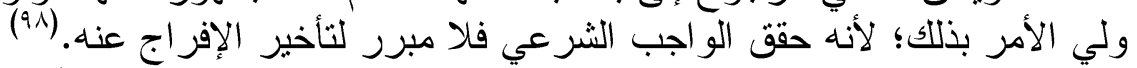

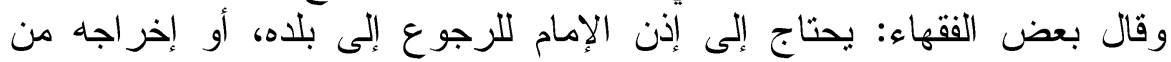

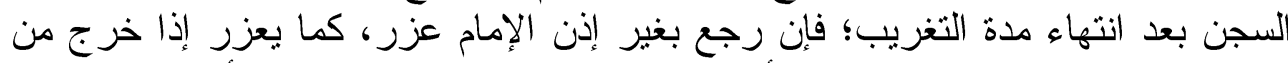

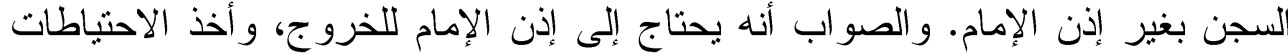

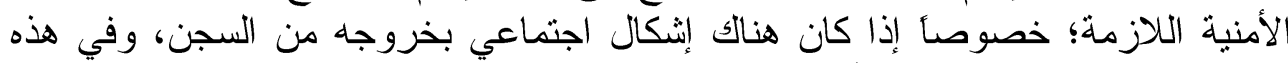

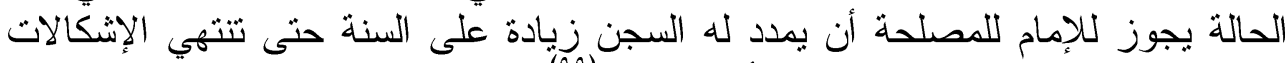

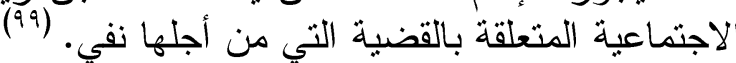

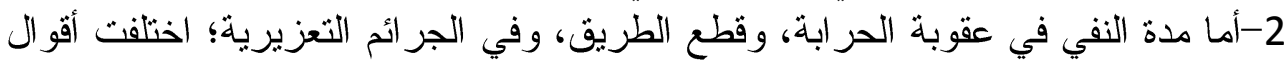

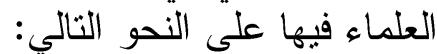

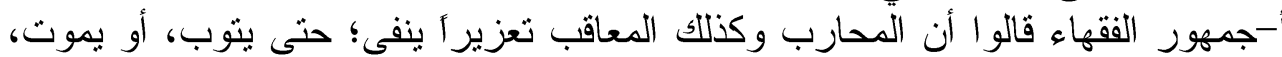

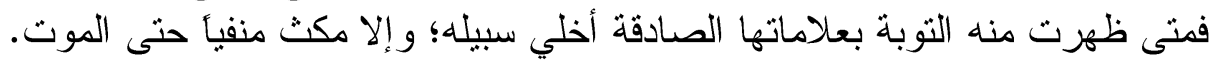

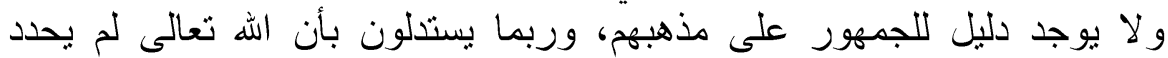

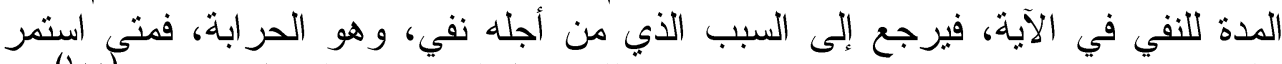

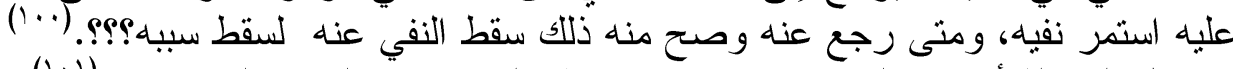

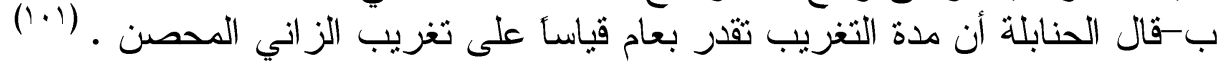

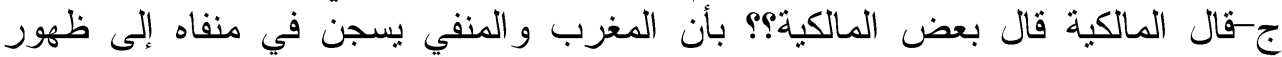

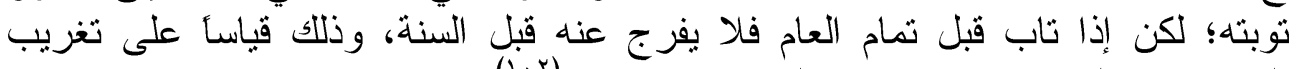

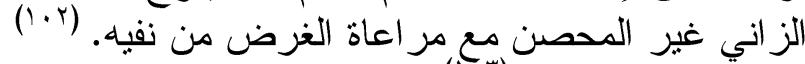

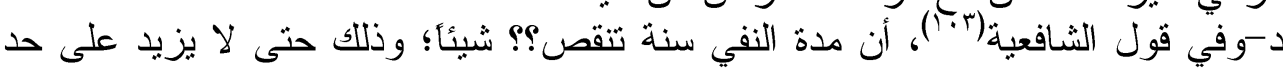

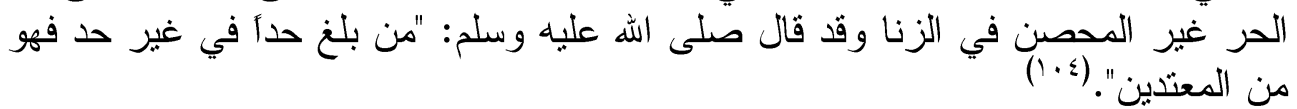

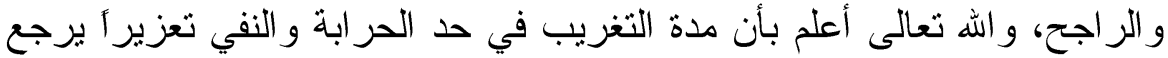

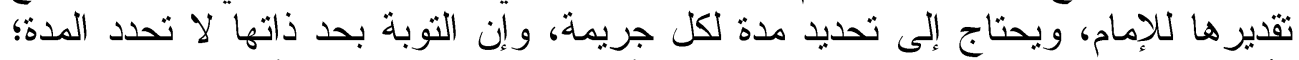

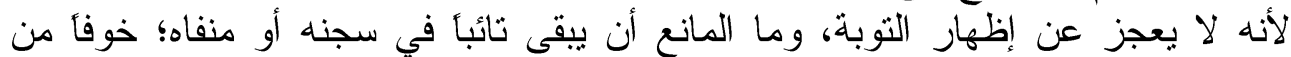

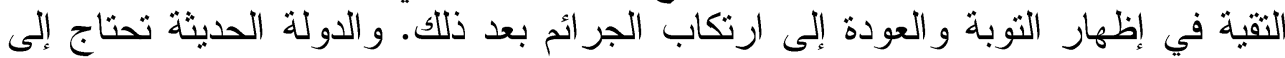
وضع ضو ابط صحيحة؛ لمنع الجر ائم، أو للمعاقبة عليها. 
فمعظم الذين في السجون لا يجدون عملا، فيميلون إلى التنين الظاهري؛ هروبأ

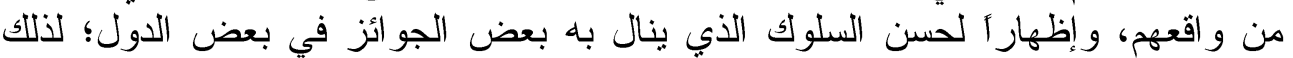
لابد من قو انين تحدد المدة لكل جريمة، وعلى المسجون إنهاء المدة المقررة و الله أعلم.

عقوبة النفي في الفقه الإسلامي جاءت عقوبة حدية في حد الحرابة بالنص

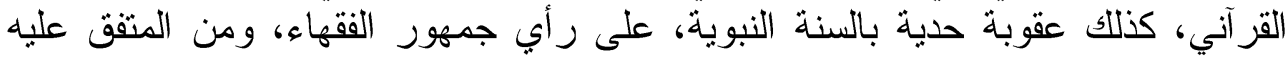

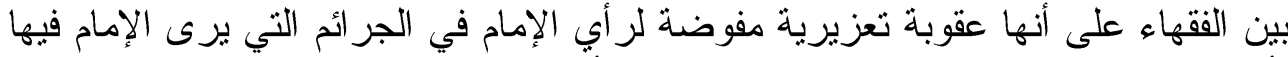

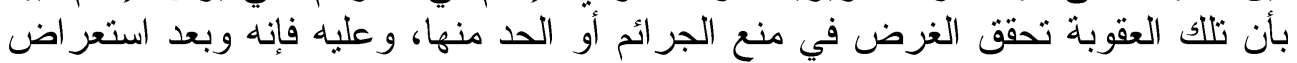
مطالب هذا البحث توصلت الد الد استة للنتائج الثالية:

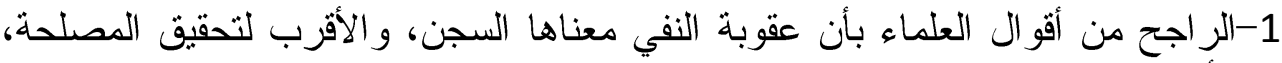

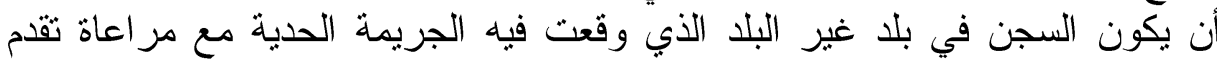

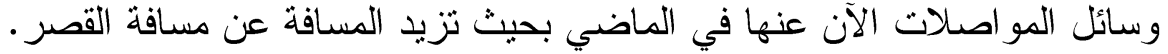

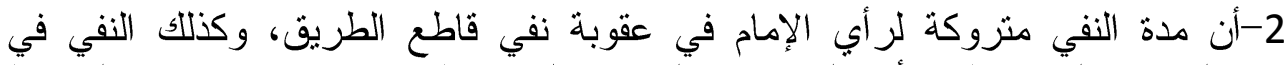

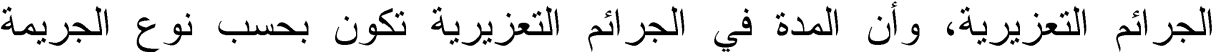
وخطورنها على الدولة والمجتمع، وللإمام التوسع في تلألك العقوبة إذا كانت نحقق لجن مصلحة.

3-عقوبة النفي في حد الزنى عقوبة حدية جزء من الحد؛ لورود الأحاديث الصحيحة فيها، و لأنها تحقق المصلحة المبتغاة من نلانك العقوبة.

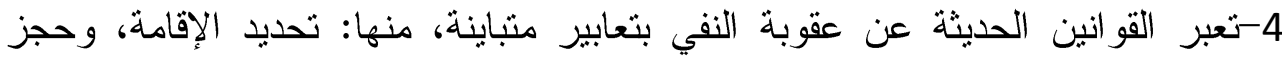

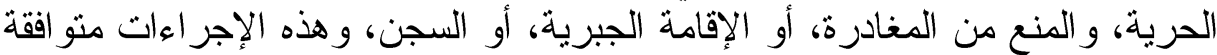
ضمنيا أحيانأ مع الهدف من عقوبة النفي الثرعية والتئي هي الإبعاد و الإخراج

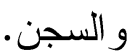
5-الدولة تتحمل تكلفة عقوبة النفي؛ لأن الراجح في معناها هو السجن، والدولة هي

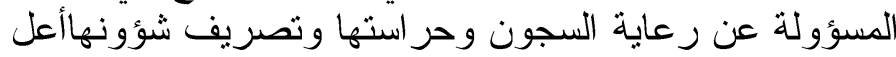




\section{Abstract \\ The punishment of negation in Islamic jurisprudence and its contemporary applications}

\section{By Abdul Hamid Ibrahim Al-Majali}

And Osama Salem Al-Sarayrah

This study deals with the punishment of banishment in Islamic jurisprudence and its contemporary applications, where the punishment of exile is mentioned in the case of harba as a hudud punishment for scaring the path and terrorizing society, and the sayings of scholars in it as a discretionary punishment.

This study concluded that the punishment for banishment is a fixed punishment in the text of the Qur'an and a fixed punishment in the Sunnah of the Prophet in the case of the virgin fornicator.

The jurists agreed that exile is a discretionary punishment that is left to the imam's opinion when it has achieved its intended purpose, which is preventing or limiting the crime as possible, and that the penalty for exile is imprisonment in a country other than the country in which the crime occurred, and that the term of imprisonment is left to the imam to achieve the interest of society and the state, and that modern laws have expressed exile In various terms, they are implicitly consistent with the purpose of the punishment, which is expulsion, deportation, and imprisonment.

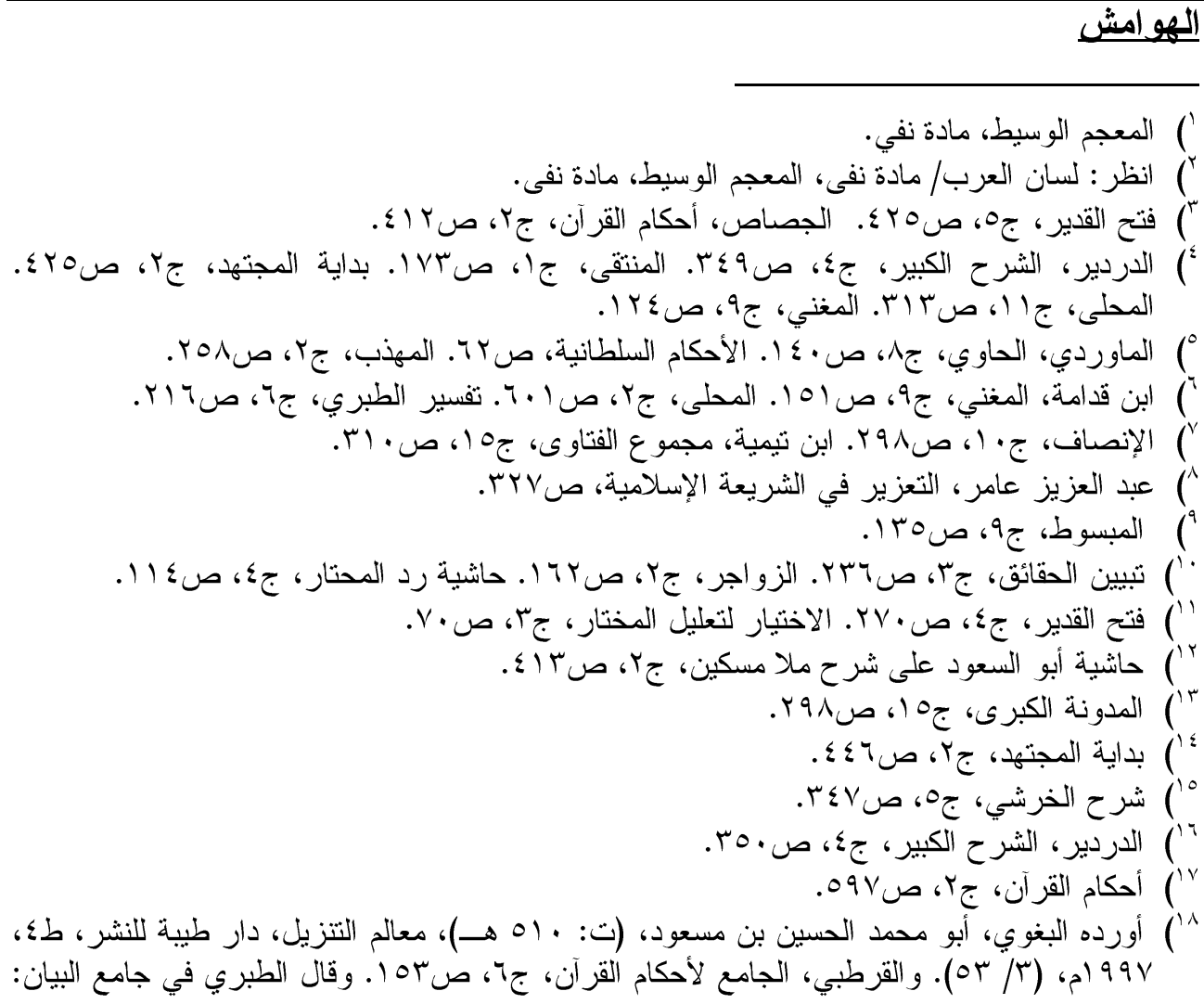




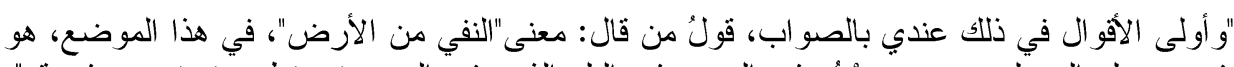

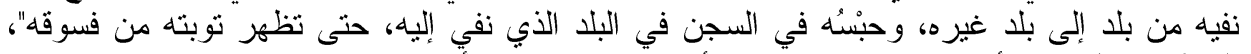

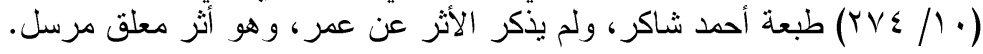

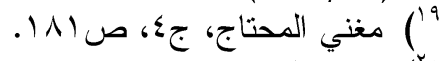

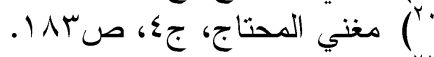

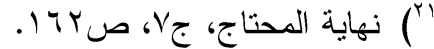

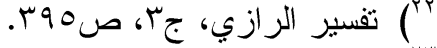

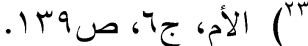

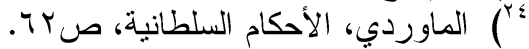

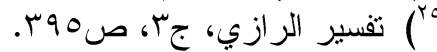

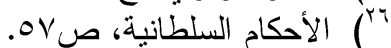

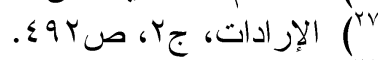

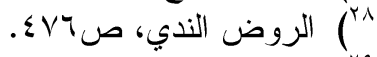

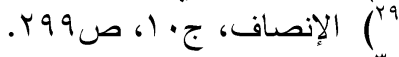

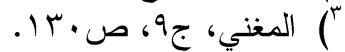

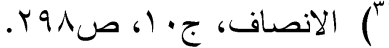

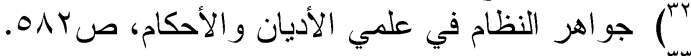

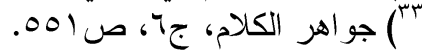

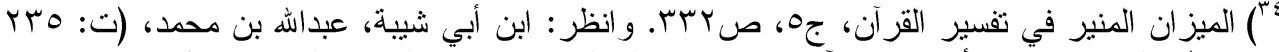

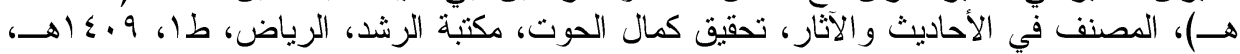

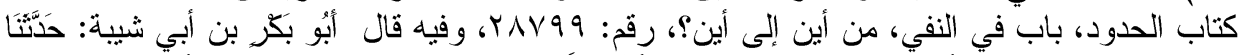

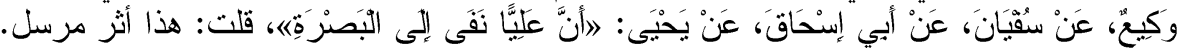

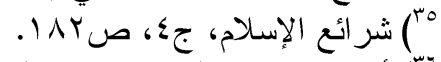

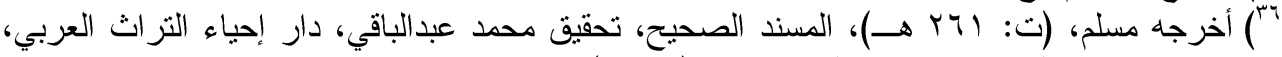

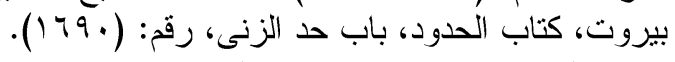

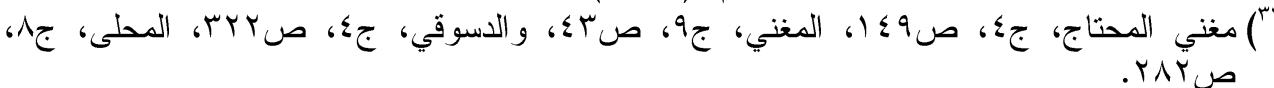

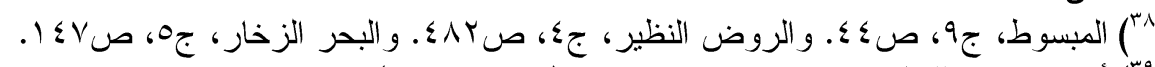

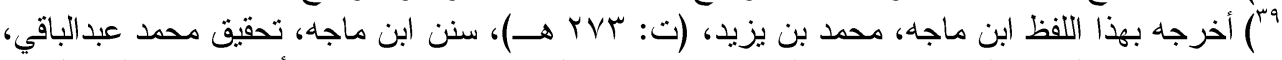

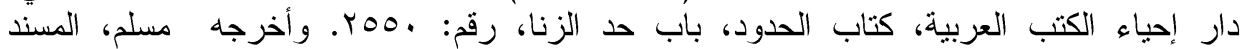

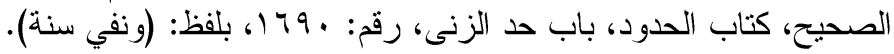

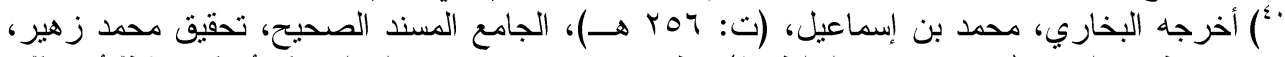

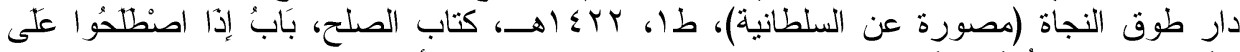

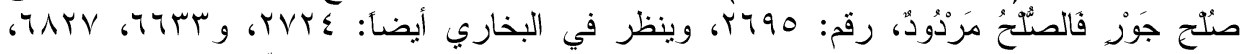

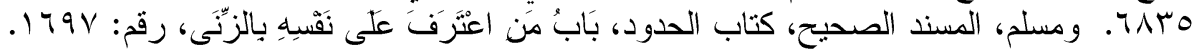

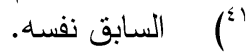

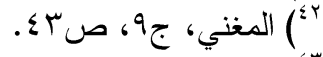

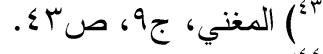

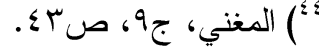




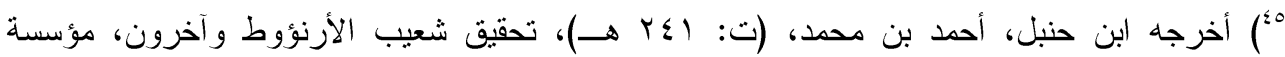

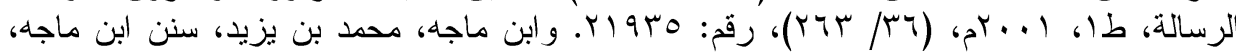

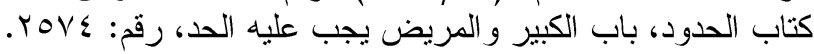

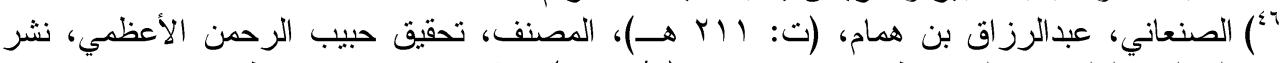

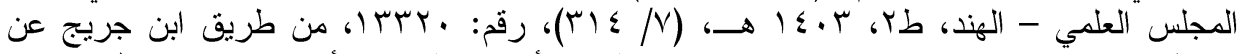

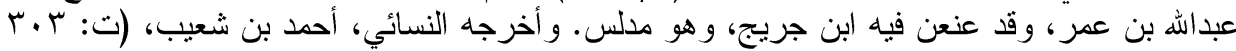

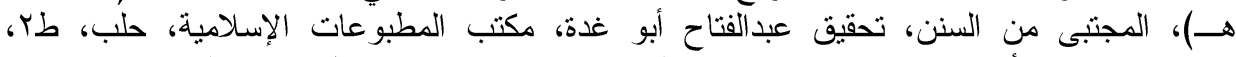

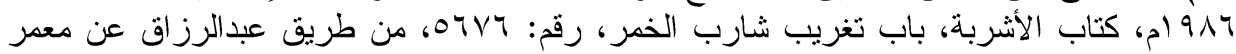

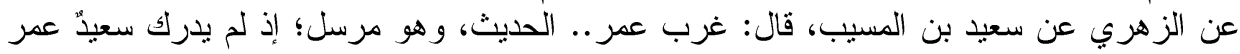

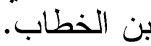

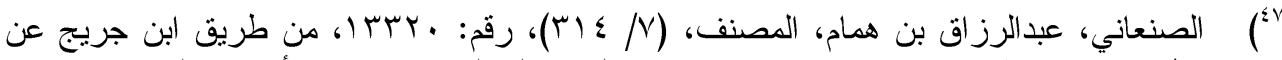

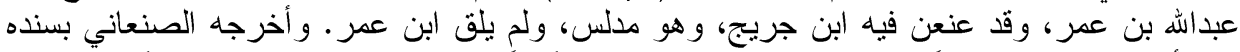

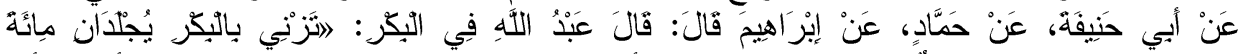

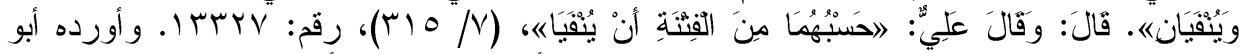

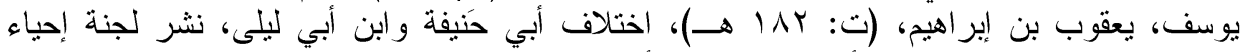

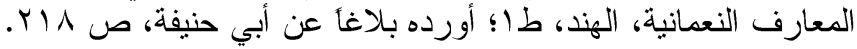

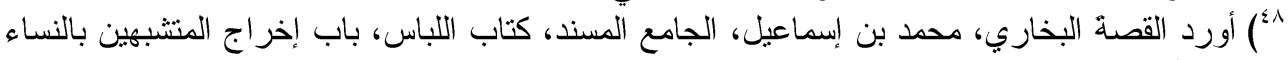

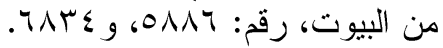

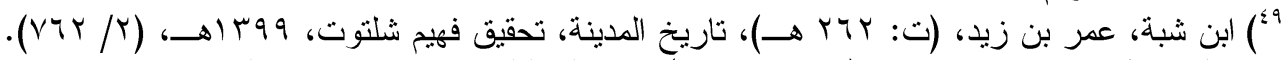

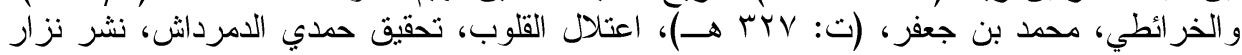

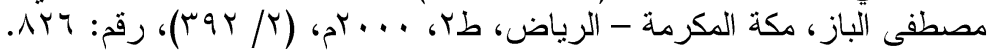

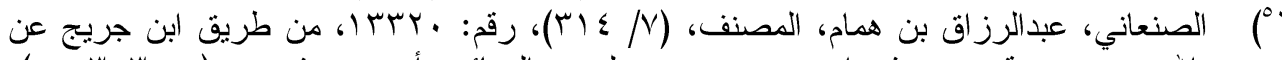

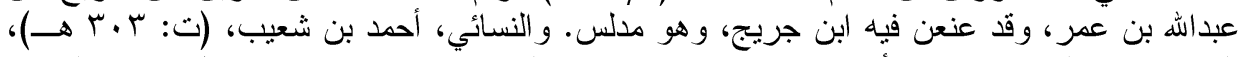

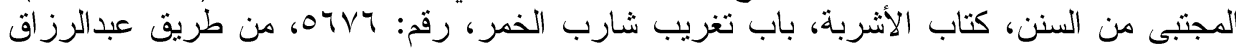

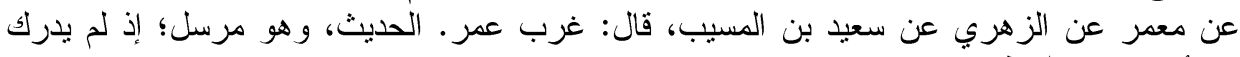

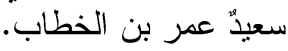

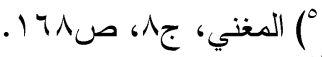

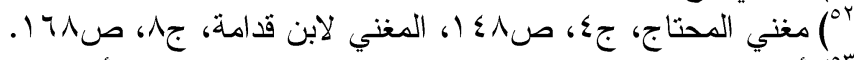

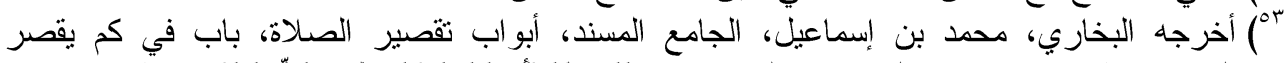

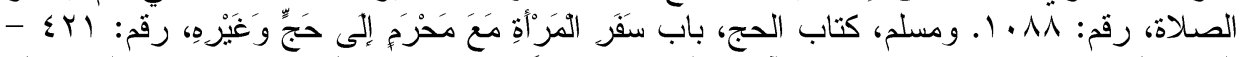

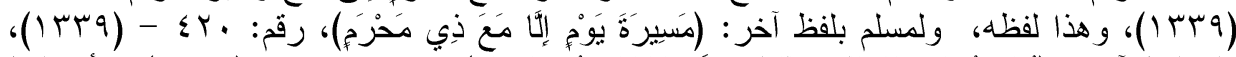

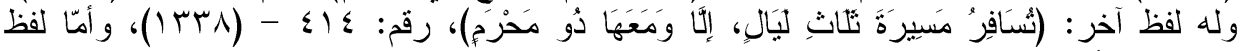

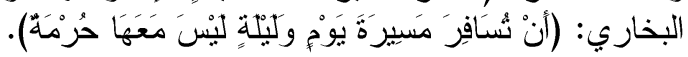

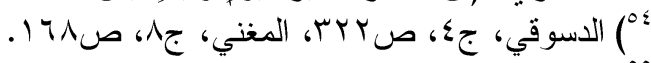

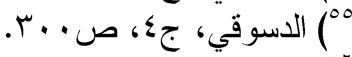

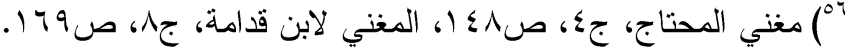

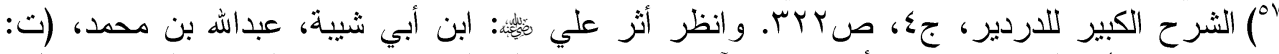

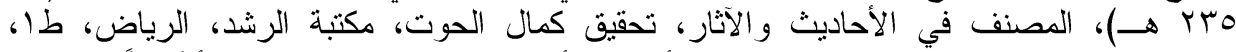

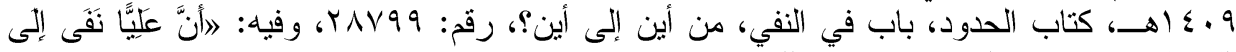

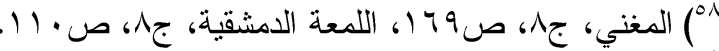

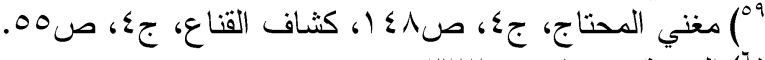

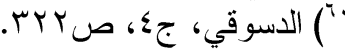

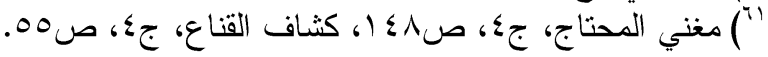




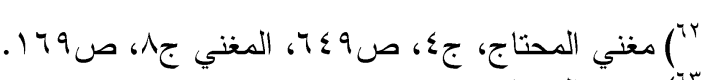

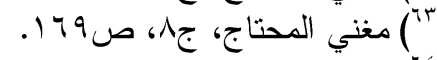

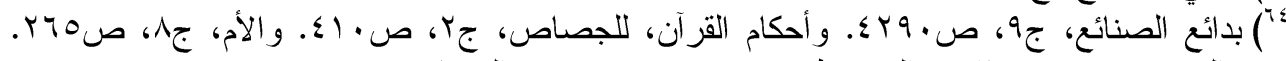

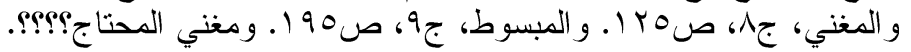

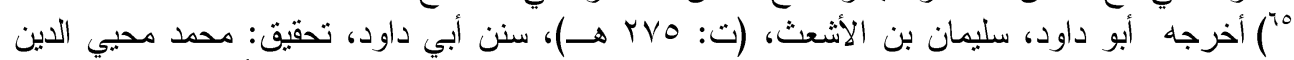

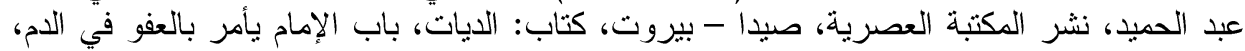

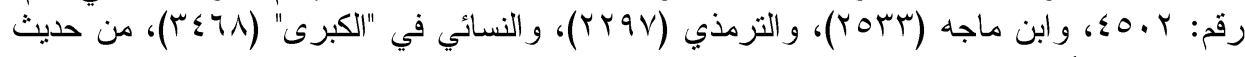

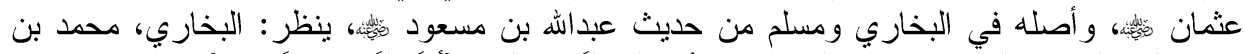

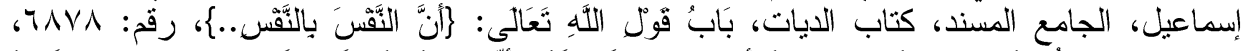

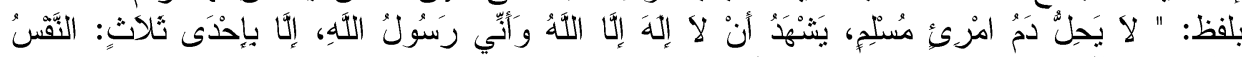

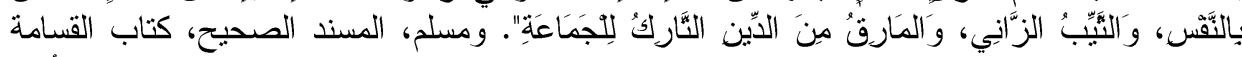

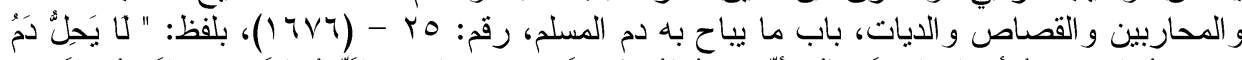

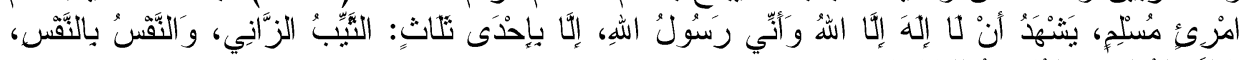

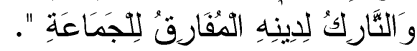

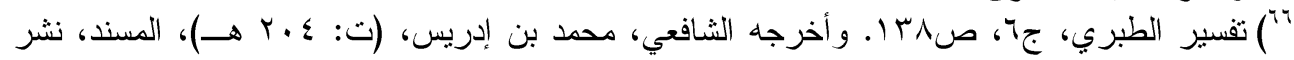

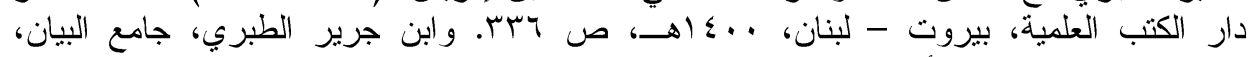

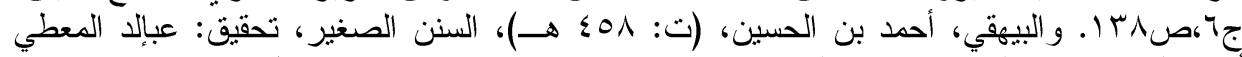

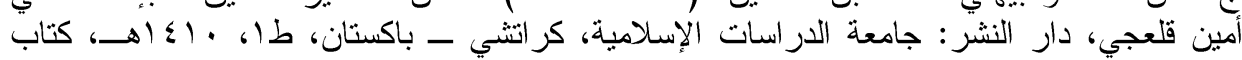

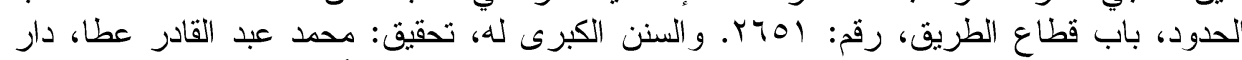

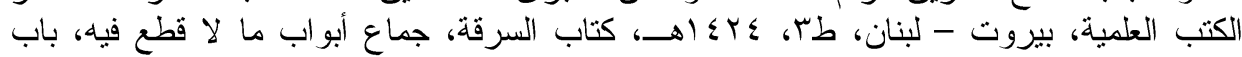

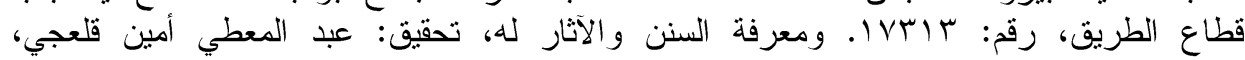

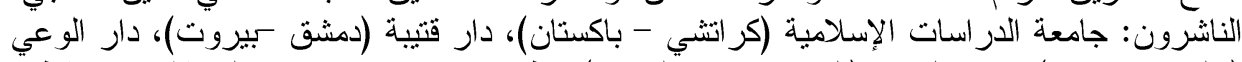

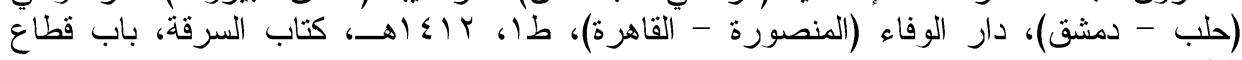

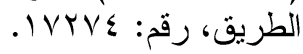

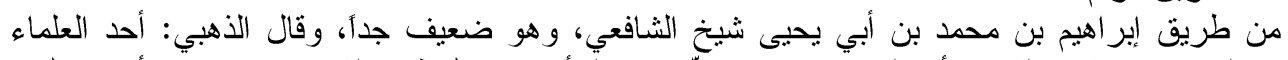

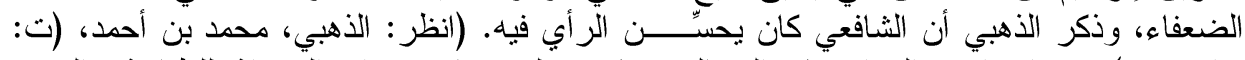

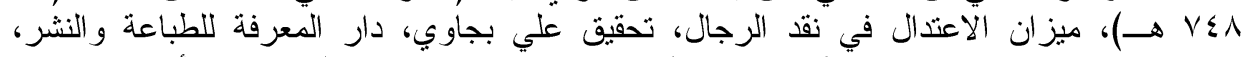

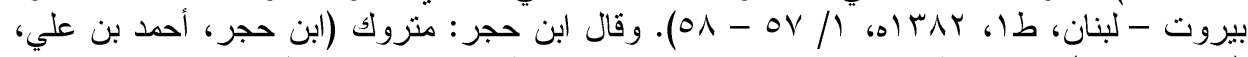

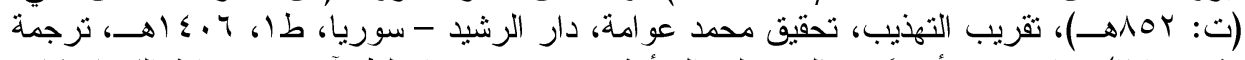

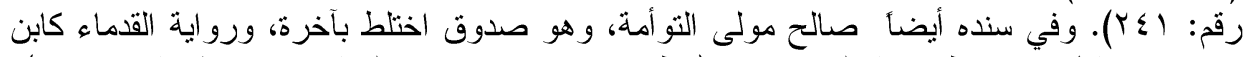

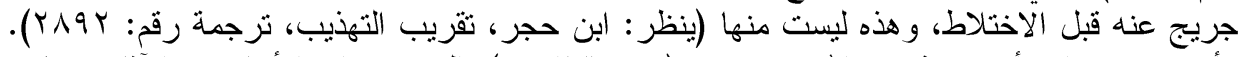

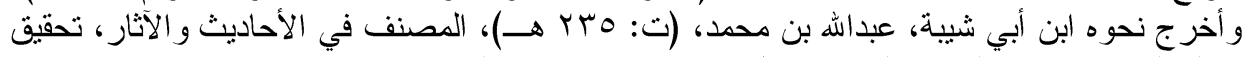

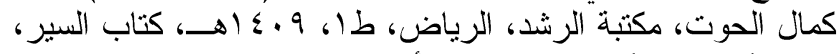

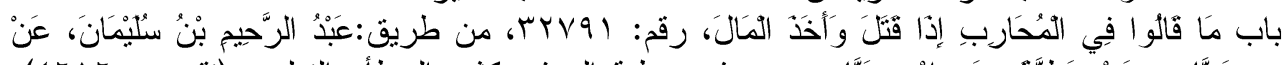

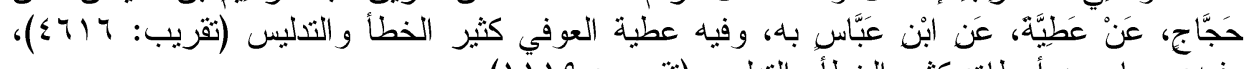

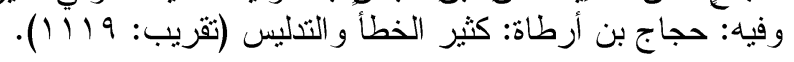

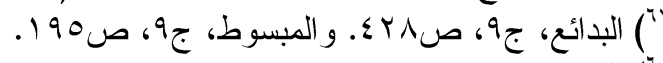

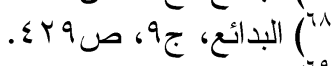

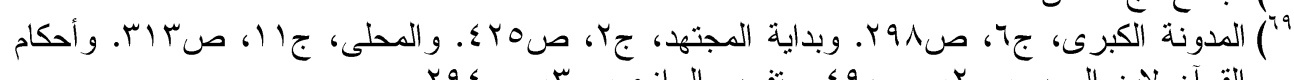

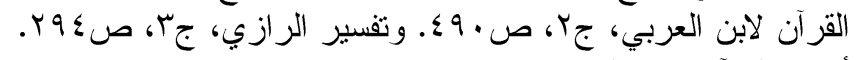

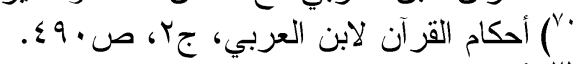

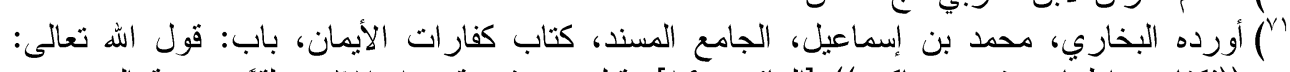

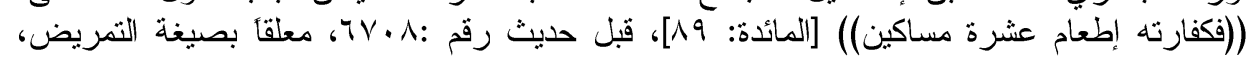




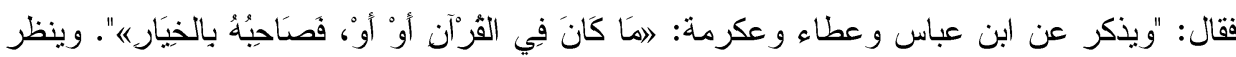

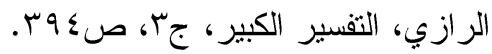

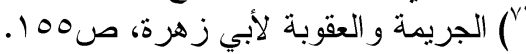

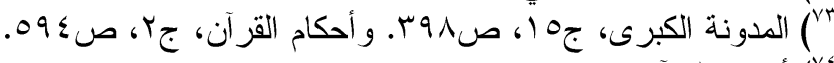
(ro

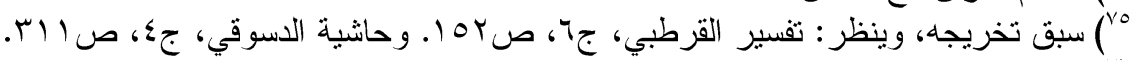

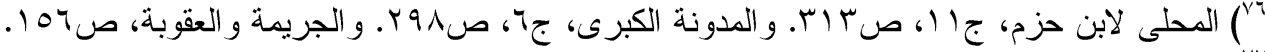

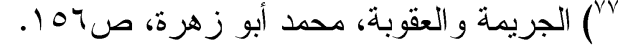

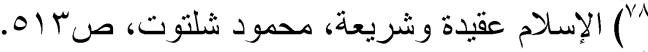

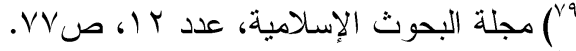

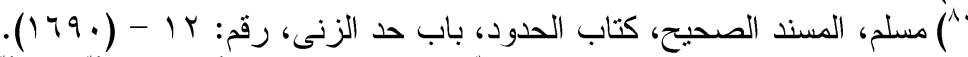

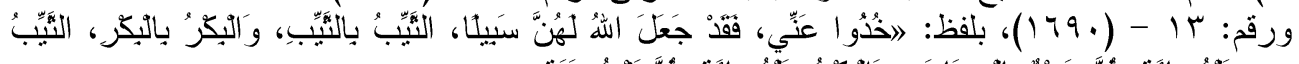

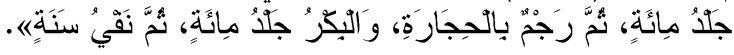

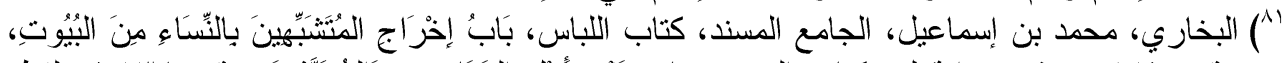

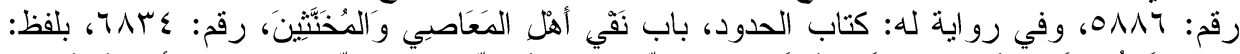

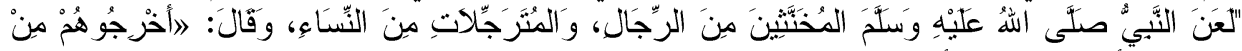

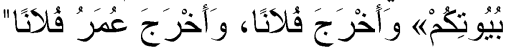

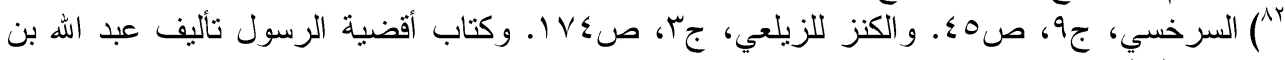

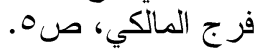

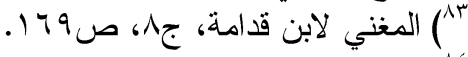

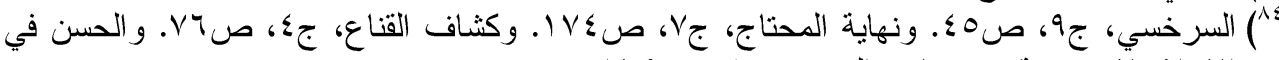

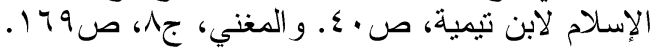

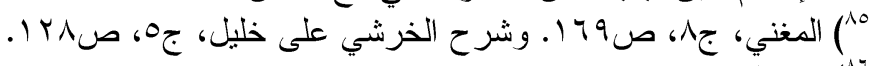

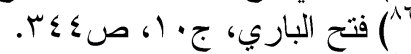

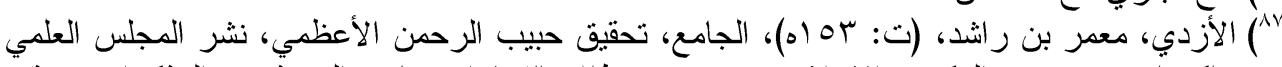

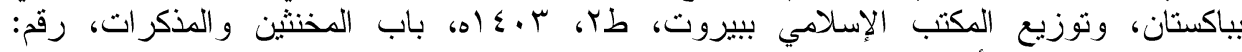

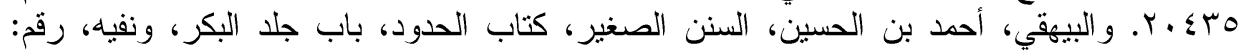

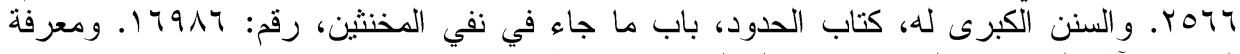

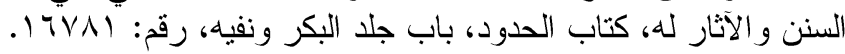

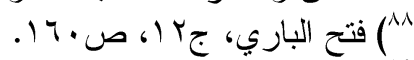

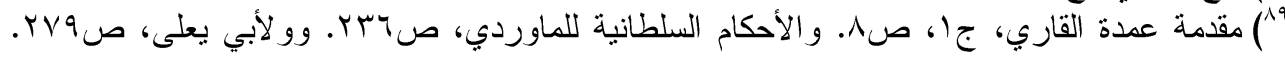

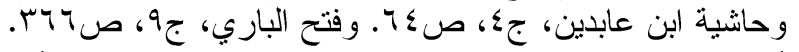

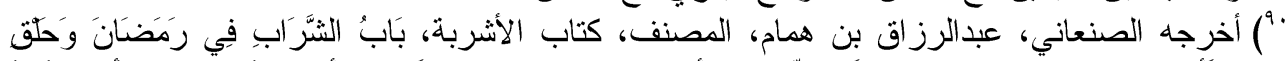

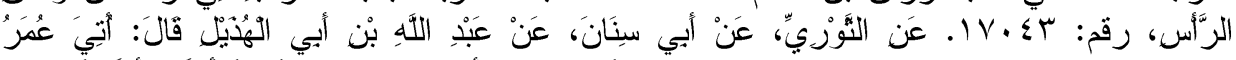

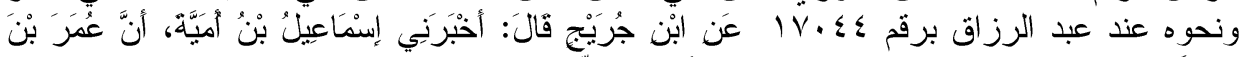

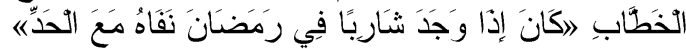

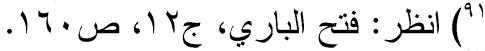

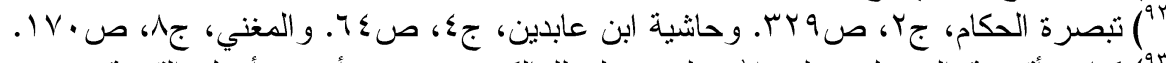

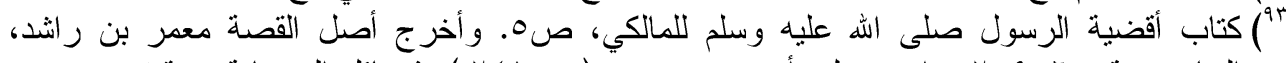

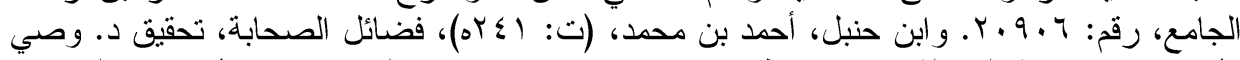

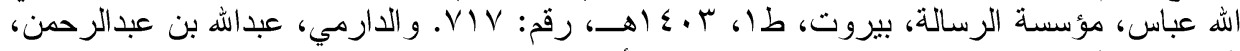

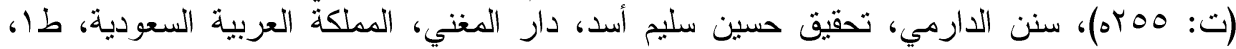

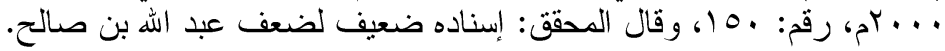




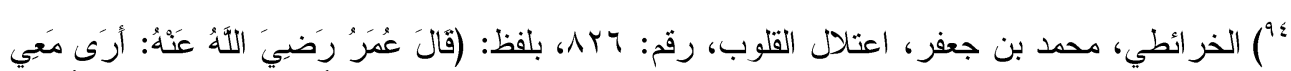

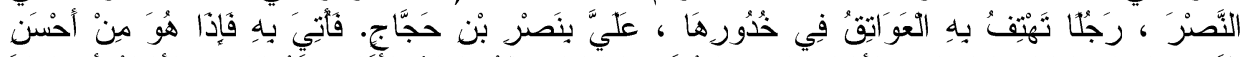

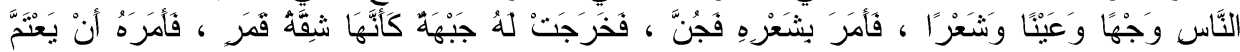

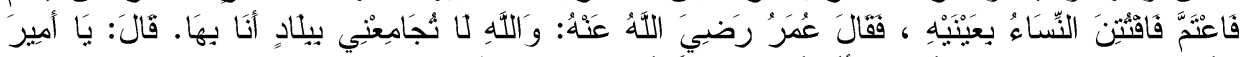

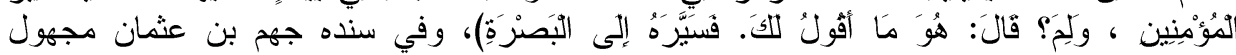

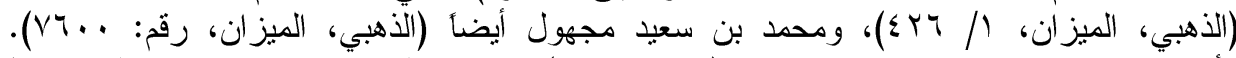

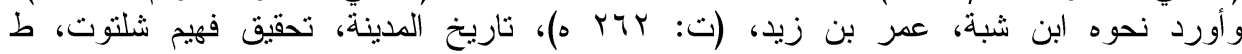

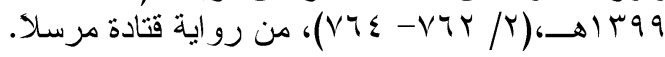
(90) سبق تخريجه.

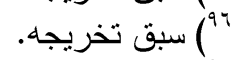

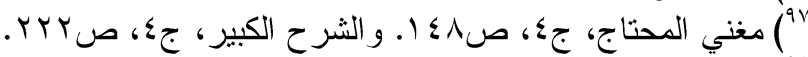

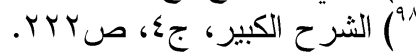

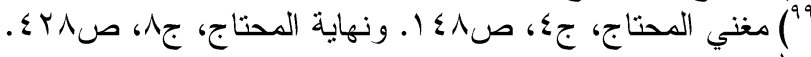

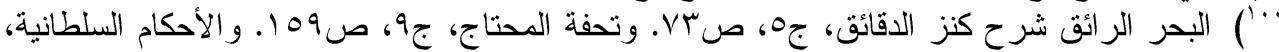

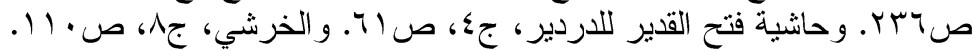

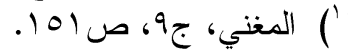

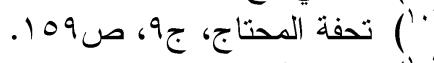

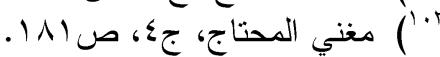

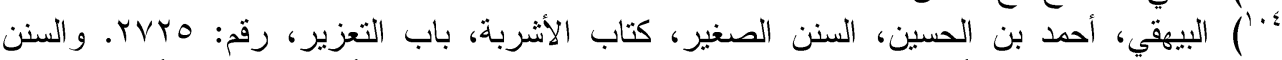

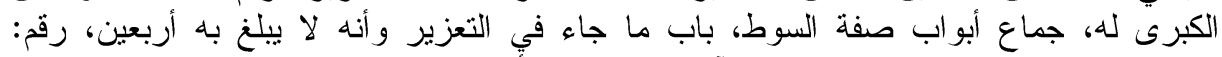

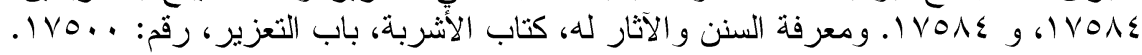

ا. أثز تطبيق الحدود في المجتمع، بحوث مؤتمر الفقه الإسلامي، 1404ه، مطابع جامعة الإمام محمد بن

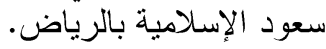

r. أحكام البغاة و المحاربين في الشريعة الإسلامية، د. خالد رشيد الجميلي، دار الحرية بغداد،.1978

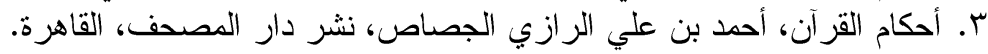

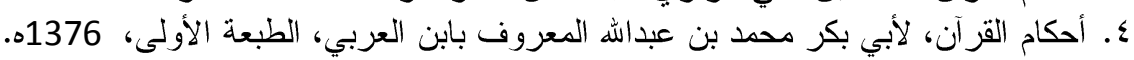

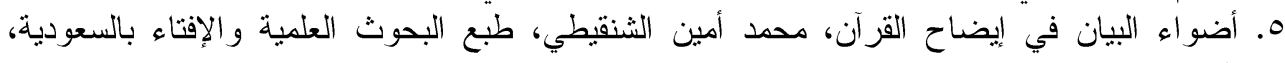

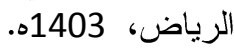

T. أعلام الموقعين عن رب العالمين، ابن القيم، مطبعة النهضة الجديدة، القاهرة، 1388ه.

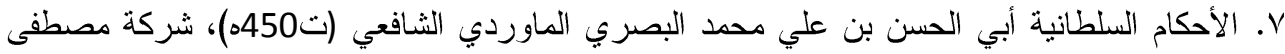

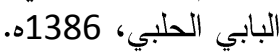

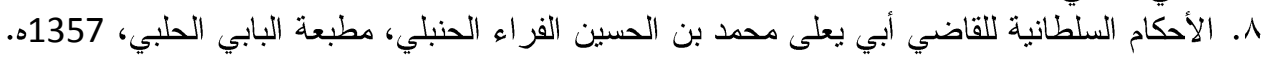

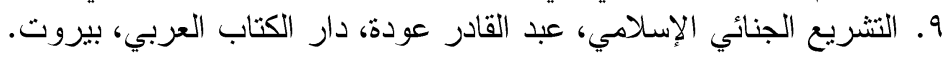

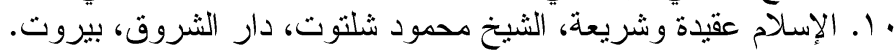

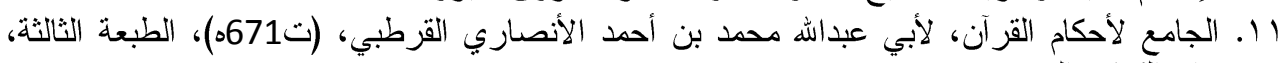
دار الكتاب المصري.

Y ا . الجريمة والعقوبة في الثريعة الإسلامية، د. محمد أبو حسان، مكتبة المنار، الزرقاء، الطبعة الأولى، ه1408 r ا ـ الجريمة و العقوبة، محمد أبو زهرة، دار الفكر العربي. 
؛ ا. الحاوي الكبير في فقه الإمام الثافعي لأبي الحسن علي بن محمد حبيب البصري ، طبعة دار الكتب

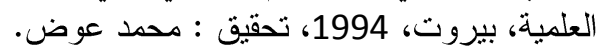

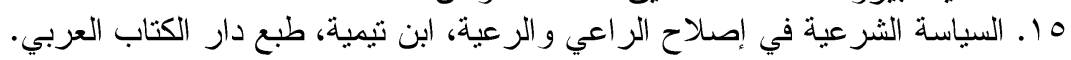

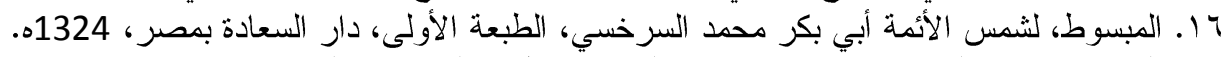

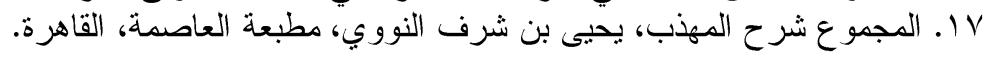

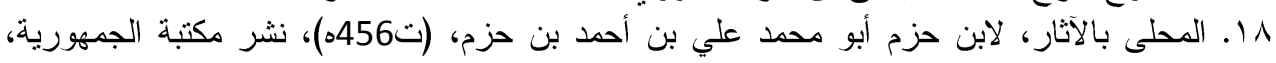
.1391

9 19. المختصر النافع لأبي قاسم نجم الدين جعفر بن الحسين علي (ت676ه)، منشورات المكتبة الأهلية،

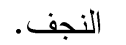
r.r. المدونة الكبرى للإمام مالك بن أنس، دار صادر بيروت.

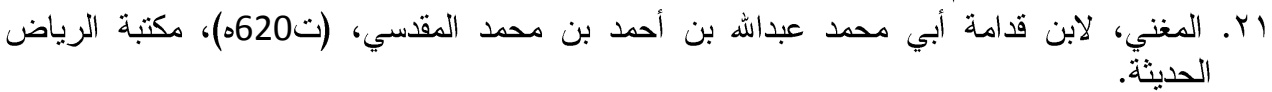

r r r . المقنع، لابن قدامة المقدسي، المطبعة السلفية.

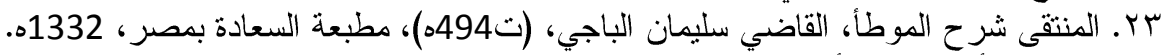

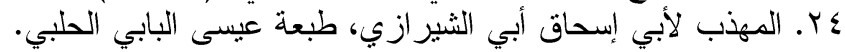

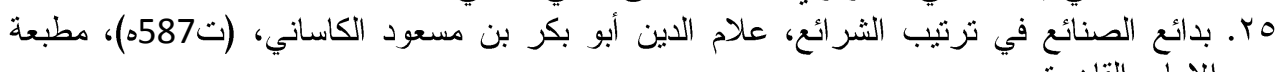

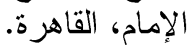

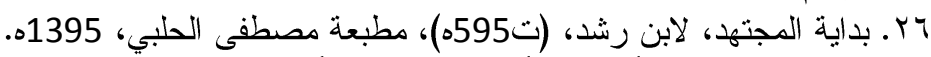

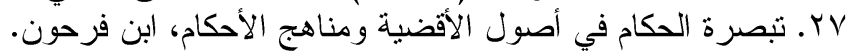

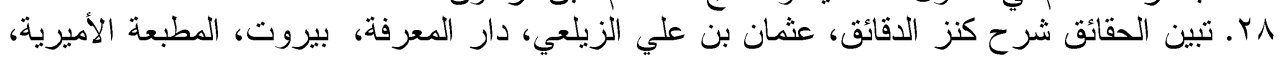
1313

وr. جامع البيان في تأويل القرآن، لأبي جعفر محمد بن جرير الطبري (ت313) 310)، مطبعة دار المعارف

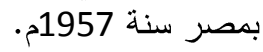
•r. جناية قطع الطريق، سامي محمد هاشم، دار النشر بالمركز العربي للاراسات الأمنية والتدريب،

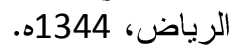
اس. جواهر النظام في علم الأديان والأحكام، تأليف عبداله بن حميد السالمي، المطبعة العربية، بمصر، 1344. 134

rr. حاشية ابن عابدين محمد الشهير، ابن عابدين، دار الطباعة المصرية 1372ه، بيروت.

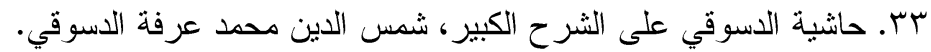

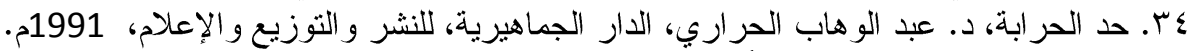

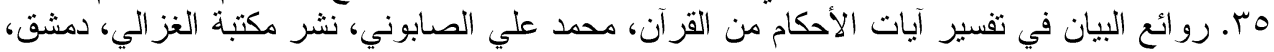

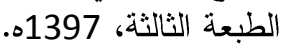

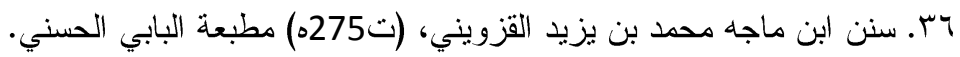

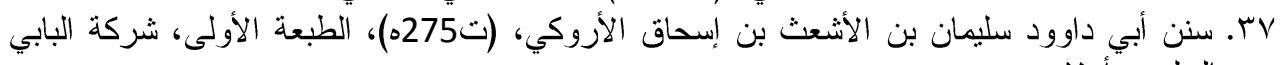

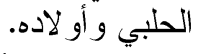

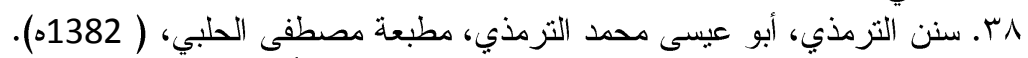

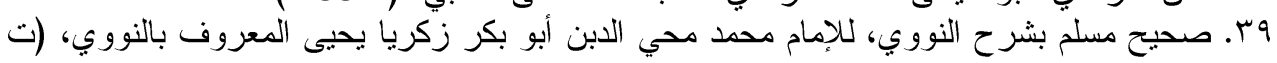

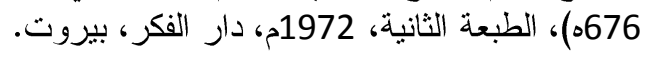
•ـ ــ فتح الباري بشرح صحيح البخاري، الحافظ ابن حجر العسقلاني، (ت852ه)، المطبعة السلفية، 1378

اءـ فتح القدير ، كمال الدين بن محمد بن عبد الو احد المعروف بابن الهام. ب ـ ـ في أصول النظام الجنائي الإسلامي، د. محمد سليم العو ا، دار المعارف، الطبعة الثانية، 1983م. 
باء. لسام العرب، للإمام أبي الفضل جمال الدين محمد بن مكرم ابن منظور الأفريقي المصري، طبعة

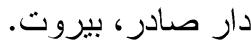

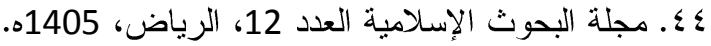

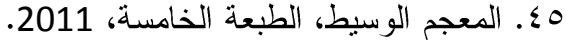

4اء. مجموع فتاوى شيخ الإسلام، اين تيمية جمع عبد الرحمن بن محمد العاصمي النجدي، طبعة 1398

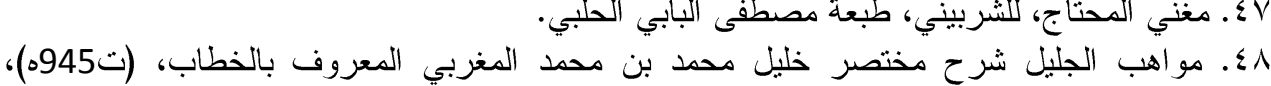

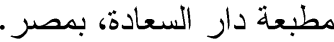

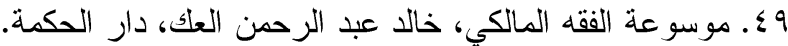

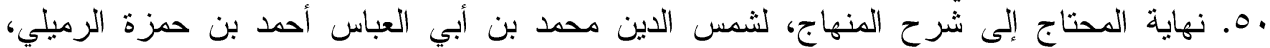

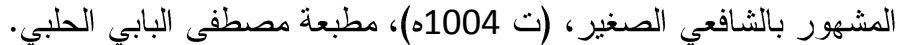
10. نيل الأوطار ، محمد بن علي الثوكاني، مطبعة مصطفى البابي الحلبي، 1004هي، 1380ه. 